\title{
Synthesis and Spectroelectrochemistry of $\mathrm{N}$-Cobaltacarborane Porphyrin Conjugates
}

\author{
Erhong Hao ${ }^{a}$, Min Zhang ${ }^{b}$, Wenbo $E^{b}$, Karl M. Kadish ${ }^{b}$, Frank R. Fronczek ${ }^{a}$, Brandy H. \\ Courtney $^{\mathrm{a}}$, and M. Graça H. Vicente ${ }^{\mathrm{a}, 1}$ \\ aDepartment of Chemistry, Louisiana State University, Baton Rouge, LA 70803, USA \\ ${ }^{b}$ Department of Chemistry, University of Houston, Houston, TX 77204, USA
}

\section{Abstract}

$\mathrm{N}$-Substituted porphyrins are well known for the distortion they exhibit of the porphyrin plane through the $\mathrm{sp}^{3}$ hybridization of one of the pyrrolenic units. They have served as model compounds in investigations of many biochemical processes. In this paper, we developed an efficient route to $N$-substituted porphyrins, and report the synthesis of a series of new $N$ substituted cobaltacarborane-porphyrins containing one or two cobaltabisdicarbollide anions linked by $\left(\mathrm{CH}_{2} \mathrm{CH}_{2} \mathrm{O}\right)_{2}$ chains to either the core porphyrin nitrogens or to a meso-aminophenyl group. These conjugates show different degrees of distortion of the porphyrin macrocycle, which affect their spectroscopic and electrochemical properties. In particular, the core $N$-substituted conjugates show significant fluorescence quenching in comparison with the non-core substituted macrocycles. The X-ray structures of two targeted core $\mathrm{N}$-cobaltacarborane porphyrin conjugates are presented. The electrochemical and spectroelectrochemical properties of these porphyrin conjugates were investigated; while the peripheral $N$-substituted cobaltacarboranylporphyrins undergo three reversible reductions and three reversible oxidations (two attributed to the porphyrin and one to the $\mathrm{Co}^{\mathrm{III}}$ cluster), the core $\mathrm{N}$-substituted porphyrins exhibit complicated electrochemical behavior with coupled chemical reactions.

\section{Keywords}

porphyrin; cobaltacarborane; reduction; oxidation

\section{INTRODUCTION}

In the past few decades, porphyrin and related compounds have assumed broad importance in diverse areas of medicine, catalysis, and molecular electronics (1). Structural modification and conformational distortion of porphyrin macrocycles are widely studied because they may have the potential to control the properties and functions of tetrapyrroles in biological systems. In particular, porphyrins with substituents at a pyrrolenic nitrogen atom, i.e. $\mathrm{N}$ substituted porphyrins, are of biochemical significance and have served as model compounds in investigations of biochemical processes (2-8). These compounds are well known for the distortion of the porphyrin plane through the $\mathrm{sp}^{3}$ hybridization of one of the pyrrolenic units. They are also powerful inhibitors of the enzyme ferrochelatase, which is essential for the formation of heme for hemoglobin, myoglobin and cytochromes, and have

\footnotetext{
${ }^{1}$ Corresponding author. Phone: (225) 578 7405, Fax: (225) 578 3458, vicente@1su.edu .

Supporting Information Available. The molecular structure of $\left[8,8^{\prime}-\mu-\left(\mathrm{C}_{2} \mathrm{H}_{5} \mathrm{O}\right)-3,3^{\prime}-\mathrm{Co}\left(1,2-\mathrm{C}_{2} \mathrm{~B}_{9} \mathrm{H}_{10}\right)_{2}\right]$, UV-visible and fluorescence spectra for porphyrins 8 and 9 , cyclic voltammograms of $\mathrm{H}_{2} \mathrm{TPP}$ and $\mathrm{H}_{2} \mathrm{OEP}$, and spectral changes of $\mathrm{H}_{2} \mathrm{TPP}$ upon the first and second oxidations. This material is available free of charge via the Internet at http://pubs.acs.org.
} 
been shown to be produced in a biochemical monooxygenation process catalyzed by cytochrome P-450 enzymes (2-8). The unique structures of synthetic $N$-substituted porphyrin derivatives has led to their investigation for potential applications in the fields of catalysts (9), molecular recognition (10,11), medicine (12) and energy transfer (13). In addition, interesting new macrocycles have been reported from the ring expansion or reduction of $N$-substituted porphyrins and analogs (14-17). Despite the potential wide range of applications of these compounds and the important role they have played in understanding biological processes, the synthetic routes currently available to obtain $\mathrm{N}$ substituted porphyrins are limited and most employ harsh conditions that result in low yields of the target molecules.

Recently, porphyrins bearing boron clusters have been identified as useful agents in boron neutron capture therapy (BNCT) of cancer because of their abilities to localize in tumors and their high boron content $(18,19)$. Among the boron clusters, the metallacarboranes and in particular the cobaltabisdicarbollide anion $\left[\mathrm{Co}\left(\mathrm{C}_{2} \mathrm{~B}_{9} \mathrm{H}_{11}\right)_{2}\right]^{-}$and its adducts have attracted much attention because of their remarkable chemical, thermal and photo stabilities (20). As part of our studies of the development of new boron-containing porphyrins and derivatives, we recently reported the synthesis of porphyrin-cobaltacarborane conjugates, via an efficient nucleophilic ring-opening reaction of $\left[3,3^{\prime}-\mathrm{Co}\left(8-\mathrm{C}_{4} \mathrm{H}_{8} \mathrm{O}_{2}-1,2-\mathrm{C}_{2} \mathrm{~B}_{9} \mathrm{H}_{10}\right)\left(1^{\prime}, 2^{\prime}-\mathrm{C}_{2} \mathrm{~B}_{9} \mathrm{H}_{11}\right)\right]$ by porphyrins containing phenol or pyridinum groups at the peripheral meso-positions (21). Herein, we report that the core porphyrin nitrogen atoms can also function as the nucleophilic species in the ring-opening reaction of $\left[3,3^{\prime}-\mathrm{Co}\left(8-\mathrm{C}_{4} \mathrm{H}_{8} \mathrm{O}_{2}-1,2-\mathrm{C}_{2} \mathrm{~B}_{9} \mathrm{H}_{10}\right)\left(1^{\prime}, 2^{\prime}-\right.\right.$ $\left.\mathrm{C}_{2} \mathrm{~B}_{9} \mathrm{H}_{11}\right)$ ], and this methodology allows the efficient synthesis of $N$-cobaltacarboranylporphyrins in high yields. Using as the starting porphyrins, free-base mesotetraphenylporphyrin $\left(\mathrm{H}_{2} \mathrm{TPP}\right)$ and octaethylporphyrin $\left(\mathrm{H}_{2} \mathrm{OEP}\right)$, both mono- and di- $\mathrm{N}$ substituted derivatives were obtained in high yields by slight modification of the reaction conditions. These compounds show strong fluorescence quenching. We also report the synthesis of two new $\mathrm{N}$-cobaltacarboranyl-porphyrins from the reaction of mono-( $p$ aminophenyl)triphenylporphyrin with $\left[3,3^{\prime}-\mathrm{Co}\left(8-\mathrm{C}_{4} \mathrm{H}_{8} \mathrm{O}_{2}-1,2-\mathrm{C}_{2} \mathrm{~B}_{9} \mathrm{H}_{10}\right)\left(1^{\prime}, 2^{\prime}-\mathrm{C}_{2} \mathrm{~B}_{9} \mathrm{H}_{11}\right)\right]$. The electrochemical and spectroelectrochemical properties for both types of compounds are reported and comparisons are made to the individual monomeric units under the same experimental conditions.

\section{EXPERIMENTAL PROCEDURES}

\section{Electrochemical and Spectroelectrochemical Measurements}

Cyclic voltammetry (CV) measurements were performed at $298 \mathrm{~K}$ on an EG\&G model 173 potentiostat coupled with an EG\&G model 175 universal programmer in deaerated $\mathrm{PhCN}$ solution containing $0.1 \mathrm{M}$ TBAP as a supporting electrolyte. A three-electrode system was utilized and consisted of a glassy carbon working electrode, a platinum wire counter electrode and a saturated calomel reference electrode (SCE). The reference electrode was separated from the bulk of the solution by a fritted-glass bridge filled with the solvent/ supporting electrolyte mixture. UV-visible spectroelectrochemical experiments were performed with a home-built thin-layer cell (22) that had a light transparent platinum net working electrode. Potentials were applied and monitored with an EG\&G PAR Model 173 potentiostat. Time evolution of the UV-visible spectra was recorded with a Hewlett-Packard Model 8453 diode array spectrophotometer.

\section{Syntheses}

All reactions were monitored by TLC using $0.25 \mathrm{~mm}$ silica gel plates with or without UV indicator (60F-254). Silica gel Sorbent Technologies 32-63 $\mu \mathrm{m}$ was used for flash column chromatography. ${ }^{1} \mathrm{H}$ - and ${ }^{13} \mathrm{C}-\mathrm{NMR}$ were obtained on either a DPX-250 or a ARX-300 
Bruker spectrometer. Chemical shifts $(\delta)$ are given in ppm relative to actone- $\mathrm{d}_{6}(2.05$ ppm, ${ }^{1} \mathrm{H} ; 206.0 \mathrm{ppm},{ }^{13} \mathrm{C}$ ) unless otherwise indicated. Electronic absorption spectra were measured on a Perkin Elmer Lambda 35 UV-Vis spectrophotometer and fluorescence spectra were measured on a Perkin Elmer LS55 spectrometer. Mass spectra were obtained on an Applied Biosystems QSTAR XL. All solvents were obtained from Fisher Scientific (HPLC grade) without further purification. $\mathrm{Cs}\left[\mathrm{Co}\left(\mathrm{C}_{2} \mathrm{~B}_{9} \mathrm{H}_{11}\right)_{2}\right]$, meso-tetraphenylporphyrin $\left(\mathrm{H}_{2} \mathrm{TPP}, \mathbf{1}\right)$ and octaethylporphyrin $\left(\mathrm{H}_{2} \mathrm{OEP}, 2\right)$ were obtained from Frontier Scientific, Logan, Utah. 5-(4-Aminophenyl)-10,15,20-triphenylporphyrin and its zinc complex were synthesized according to a literature method (23). Intensity data were collected for the $\mu$ EtO-cobaltacarborane, porphyrin $\mathbf{3}$ (as the monohydrate, bis pyridine solvate) and porphyrin 4 at $\mathrm{T}=110 \mathrm{~K}$ using graphite monochromated MoK $\alpha$ radiation $(\lambda=0.71073 \AA$ ) on a Nonius KappaCCD diffractometer fitted with an Oxford Cryostream cooler. Data reduction included absorption corrections by the multiscan method, using HKL SCALEPACK (24). Structures were solved by direct methods and refined by full-matrix least squares, using SHELXL97 (25).

\section{N-Cobaltacarborane tetraphenylporphyrin (3)}

$\mathrm{H}_{2} \mathrm{TPP}(\mathbf{1})(61.4 \mathrm{mg}, 0.10 \mathrm{mmol})$ and $\left[3,3^{\prime}-\mathrm{Co}\left(8-\mathrm{C}_{4} \mathrm{H}_{8} \mathrm{O}_{2}-1,2-\mathrm{C}_{2} \mathrm{~B}_{9} \mathrm{H}_{10}\left(1^{\prime}, 2^{\prime}-\mathrm{C}_{2} \mathrm{~B}_{9} \mathrm{H}_{10}\right)\right]\right.$ $(65.4 \mathrm{mg}, 0.16 \mathrm{mmol})$ were dissolved in ODCB $(25 \mathrm{~mL})$. The reaction solution was heated at $140{ }^{\circ} \mathrm{C}$ and the color changed to green in about 15 minutes. Two hours later, TLC indicated no starting $\mathrm{H}_{2}$ TPP left and the reaction was stopped by cooling. The reaction mixture was directly loaded on silica gel column using toluene to elute ODCB and trace $\mathrm{H}_{2} \mathrm{TPP}$. Then the title porphyrin was eluted using dichloromethane and recrystallized from chloroform/hexane. After drying under vacuum, porphyrin 3 was obtained in $81 \%$ yield $(82.8 \mathrm{mg})$, along with $4.7 \%(6.8 \mathrm{mg})$ of porphyrin $\mathbf{5}$. For the title porphyrin, HRMS (MALDI-TOF) for $\mathrm{C}_{52} \mathrm{H}_{59} \mathrm{~N}_{4} \mathrm{O}_{2} \mathrm{~B}_{18} \mathrm{Co:} \mathrm{m} / z$ calcd, 1025.5788 , found 1025.5717 . ${ }^{1} \mathrm{H}-\mathrm{NMR}$ $\left(\mathrm{CDCl}_{3}\right): 9.32(\mathrm{~d}, 2 \mathrm{H}, \mathrm{J}=5.0 \mathrm{~Hz}, \beta-\mathrm{H}), 9.08(\mathrm{~d}, 2 \mathrm{H}, \mathrm{J}=5.0 \mathrm{~Hz}, \beta-\mathrm{H}), 8.85(\mathrm{~s}, 2 \mathrm{H}, \beta-\mathrm{H}), 8.54$ (b, 4H, o-phenyl-H), 8.32 (d, 2H, J = 7.75, o-phenyl-H), 8.23 (d, 2H, J = 7.75, o-phenyl-H), 8.15 (s, $2 \mathrm{H}, \beta-\mathrm{H}), 8.00$ (m, 6H, m, p-phenyl-H), 7.87 (m, 6H, m, p-phenyl-H), 3.91 (s, 2H, car- $\mathrm{H}), 3.30(\mathrm{~s}, 2 \mathrm{H}, \mathrm{car}-\mathrm{H}), 3.07\left(\mathrm{t}, 2 \mathrm{H}, \mathrm{OCH}_{2}\right), 2.71\left(\mathrm{t}, 2 \mathrm{H}, \mathrm{OCH}_{2}\right), 0.71\left(\mathrm{t}, 2 \mathrm{H}, \mathrm{OCH}_{2}\right)$, 0.1-4.0 (br, 17H, BH), - $4.83\left(\mathrm{t}, 2 \mathrm{H}, \mathrm{NCH}_{2}\right)$. UV-Vis $\left(\mathrm{CH}_{2} \mathrm{Cl}_{2}\right) \lambda_{\max }(\mathrm{nm}) 450(\varepsilon 320,500)$, $613(13,800), 669(38,300)$.

Crystal data for 3: $\mathrm{C}_{52} \mathrm{H}_{59} \mathrm{~B}_{18} \mathrm{CoN}_{4} \mathrm{O}_{2} \cdot 2 \mathrm{C}_{5} \mathrm{H}_{5} \mathrm{~N} \cdot \mathrm{H}_{2} \mathrm{O}$, dark blue, $\mathrm{FW}=1201.76$, triclinic, space group P-1, $a=14.488(2), b=15.269(2), c=15.850(3) \AA, \alpha=66.662(7), \beta=76.501(6)$, $\gamma=83.995(7)^{\circ}, V=3130.2(8) \AA^{3}, Z=2, D_{\text {calc }}=1.275 \mathrm{~g} \mathrm{~cm}^{-3}, \mu=0.326 \mathrm{~mm}^{-1}, \mathrm{~T}=110 \mathrm{~K}$, $\theta_{\max }=32.6^{\circ}, 73501$ measured reflections, 22598 independent $\left(\mathrm{R}_{\mathrm{int}}=0.118\right), 10070$ with $\mathrm{I}>$ $2 \sigma(\mathrm{I}), \mathrm{R}_{1}=0.094, \mathrm{wR}\left(\mathrm{F}^{2}\right)=0.163, \mathrm{~S}=1.030,813$ refined parameters, $\Delta \rho_{\max }=0.98 \mathrm{e}^{-3}$, $\Delta \rho_{\min }=-1.06 \mathrm{e}^{-3}$.

\section{$\mathrm{N}$-Cobaltacarborane octaethylporphyrin (4)}

$\mathrm{H}_{2} \mathrm{OEP}(2)$ (53.5 mg, $\left.0.10 \mathrm{mmol}\right)$ and $\left[3,3^{\prime}-\mathrm{Co}\left(8-\mathrm{C}_{4} \mathrm{H}_{8} \mathrm{O}_{2}-1,2-\mathrm{C}_{2} \mathrm{~B}_{9} \mathrm{H}_{10}\left(1^{\prime}, 2^{\prime}-\mathrm{C}_{2} \mathrm{~B}_{9} \mathrm{H}_{10}\right)\right]\right.$ $(43.3 \mathrm{mg}, 0.11 \mathrm{mmol})$ were dissolved in $10 \mathrm{~mL}$ of ODCB. The reaction solution was stirred at $140{ }^{\circ} \mathrm{C}$ for 2 hours until TLC indicated no $\mathrm{H}_{2} \mathrm{OEP}$ left. The reaction mixture was purified on a silica gel column using dichloromethane/hexane for elution. The first purple fraction was collected, recrystallized from chloroform/hexane and dried under vacuum to yield the title porphyrin (86.1 mg, 89\%). HRMALDI-TOF-MS for $\mathrm{C}_{44} \mathrm{H}_{75} \mathrm{~N}_{4} \mathrm{O}_{2} \mathrm{~B}_{18} \mathrm{CoNa}: \mathrm{m} / z$ calcd, $968.6934[\mathrm{M}+\mathrm{Na}]^{+}$, found 968.6957. ${ }^{1} \mathrm{H}-\mathrm{NMR}\left(\mathrm{CDCl}_{3}\right): 10.67(\mathrm{~s}, 2 \mathrm{H}$, meso-H), $10.41(\mathrm{~d}$, $2 \mathrm{H}$, meso-H), 4.28-4.42 (m, 8H, $\left.\mathrm{CH}_{2}\right), 4.18-4.22(\mathrm{~m}, 2 \mathrm{H}$, car- $\mathrm{H}), 4.04-4.15\left(\mathrm{~m}, 8 \mathrm{H}, \mathrm{CH}_{2}\right)$, 3.59 (brs, $2 \mathrm{H}$, car- $\mathrm{H}), 3.02-3.05\left(\mathrm{~m}, 2 \mathrm{H}, \mathrm{OCH}_{2}\right), 2.27-2.30\left(\mathrm{~m}, 2 \mathrm{H}, \mathrm{OCH}_{2}\right), 1.96-2.01$ (t, $\left.12 \mathrm{H}, \mathrm{CH}_{3}\right), 1.47-1.53\left(\mathrm{t}, 12 \mathrm{H}, \mathrm{CH}_{3}\right), 0.09-0.22\left(\mathrm{~m}, 2 \mathrm{H}, \mathrm{OCH}_{2}\right), 0.1-4.0(\mathrm{br}, 17 \mathrm{H}, \mathrm{BH}),-$ 
5.60--5.57 (m, 2H, $\left.\mathrm{NCH}_{2}\right)$. UV-Vis (acetone) $\lambda_{\max }(\mathrm{nm}) 400(\varepsilon 145,500), 539(9,200), 562$ $(12,400), 581(10,200)$.

Crystal data for 4: $\mathrm{C}_{44} \mathrm{H}_{75} \mathrm{~B}_{18} \mathrm{CoN}_{4} \mathrm{O}_{2}, \mathrm{FW}=945.59$, garnet red, triclinic, space group P-1, $a=11.140(7), b=15.492(8), c=16.413(11) \AA, \alpha=64.83(3), \beta=87.51(3), \gamma=84.12(4)^{\circ}$, $\mathrm{V}=2550(3) \AA^{3}, \mathrm{Z}=2, \mathrm{D}_{\text {calc }}=1.231 \mathrm{~g} \mathrm{~cm}^{-3}, \mu=0.378 \mathrm{~mm}^{-1}, \mathrm{~T}=110 \mathrm{~K}, \theta_{\max }=22.9^{\circ}, 21636$ measured reflections, 6832 independent $\left(\mathrm{R}_{\text {int }}=0.074\right), 4358$ with $\mathrm{I}>2 \delta(\mathrm{I}), \mathrm{R}_{1}=0.070$, $\mathrm{wR}\left(\mathrm{F}^{2}\right)=0.126, \mathrm{~S}=1.086,628$ refined parameters, $\Delta \rho_{\max }=0.25 \mathrm{e} \AA^{-3}, \Delta \rho_{\min }=-0.35 \mathrm{e}^{-3}$.

\section{N,N-Dicobaltacarborane tetraphenylporphyrin (5)}

Mono-substituted porphyrin 3 (26.0 mg, $0.025 \mathrm{mmol})$, [3,3'- $\mathrm{Co}\left(8-\mathrm{C}_{4} \mathrm{H}_{8} \mathrm{O}_{2}-1,2-\mathrm{C}_{2} \mathrm{~B}_{9} \mathrm{H}_{10}\left(1^{\prime}\right.\right.$, $\left.\left.2^{\prime}-\mathrm{C}_{2} \mathrm{~B}_{9} \mathrm{H}_{10}\right)\right](20.1 \mathrm{mg}, 0.05 \mathrm{mmol})$ and $\mathrm{K}_{2} \mathrm{CO}_{3}(35 \mathrm{mg}, 0.25 \mathrm{mmol})$ were stirred in ODCB $(10 \mathrm{~mL})$ and then the reaction mixture was heated to $140{ }^{\circ} \mathrm{C}$ until the disappearance of starting porphyrin $\mathbf{3}$ (monitored by TLC). The reaction mixture was purified on a silica gel column using dichloromethane/ethyl acetate for elution. The main green fraction was collected, recrystallized from chloroform/hexane and dried under vacuum to yield the title porphyrin (26.6 mg, 73\%). HRMALDI-TOF-MS for $\mathrm{C}_{60} \mathrm{H}_{87} \mathrm{~N}_{4} \mathrm{O}_{4} \mathrm{~B}_{36} \mathrm{Co}_{2} \mathrm{Na}: \mathrm{m} / z$ calcd, 1458.8903, found $1458.8850 ; \mathrm{m} / \mathrm{z}$ calcd, $1481.8801[\mathrm{M}+\mathrm{Na}]^{+}$, found $1481.8874 ; \mathrm{m} / \mathrm{z}$ calcd, 1435.9006 [M-Na] ${ }^{-}$, found 1435.9014. ${ }^{1} \mathrm{H}-\mathrm{NMR}$ (acetone- $\mathrm{d}_{6}$ ): $8.97(\mathrm{~d}, 2 \mathrm{H}, \mathrm{J}=4.9 \mathrm{~Hz}, \beta-\mathrm{H})$, $8.79(\mathrm{~m}, 4 \mathrm{H}, \beta-\mathrm{H}), 8.53$ (b, 2H, o-phenyl-H), 8.33 (m, 4H, o-phenyl-H), 8.17 (t, 2H, ophenyl-H), 8.01 (m, 9H, m, p-phenyl-H), 7.91 (m, 3H, m, p-phenyl-H), 7.77 (d, 2H, J = 4.7, $\beta-\mathrm{H}$ ), 4.24 (brs, $4 \mathrm{H}, \mathrm{car}-\mathrm{H}$ ), 3.48 (br s, $4 \mathrm{H}, \mathrm{car}-\mathrm{H}$ ), 2.93 (brs, $4 \mathrm{H}, \mathrm{OCH}_{2}$ ), 2.49 (brs, $2 \mathrm{H}$, $\left.\mathrm{OCH}_{2}\right), 2.43$ (brs, $2 \mathrm{H}, \mathrm{OCH}_{2}$ ), 0.69 (brs, $4 \mathrm{H}, \mathrm{OCH}_{2}$ ), 0.1-4.0 (br, 34H, BH), -2.64 (s, $1 \mathrm{H}$, $\mathrm{NH}),-4.30\left(\mathrm{~m}, 2 \mathrm{H}, \mathrm{NCH}_{2}\right),-5.83\left(\mathrm{~m}, 2 \mathrm{H}, \mathrm{NCH}_{2}\right)$. UV-Vis $\left(\mathrm{CH}_{2} \mathrm{Cl}_{2}\right) \lambda_{\max }(\mathrm{nm}) 465(\varepsilon$ 285,950), $696(58,250)$.

\section{$\mathrm{N}, \mathrm{N}$-Dicobaltacarborane octaethylporphyrin (6)}

Mono-substituted porphyrin 4 (48.5 mg, $0.05 \mathrm{mmol})$, [3,3'- $\mathrm{Co}\left(8-\mathrm{C}_{4} \mathrm{H}_{8} \mathrm{O}_{2}-1,2-\mathrm{C}_{2} \mathrm{~B}_{9} \mathrm{H}_{10}\left(1^{\prime}\right.\right.$, $\left.2^{\prime}-\mathrm{C}_{2} \mathrm{~B}_{9} \mathrm{H}_{10}\right)$ ] (30.5 mg, $\left.0.075 \mathrm{mmol}\right)$ and $\mathrm{NaHCO}_{3}(42.3 \mathrm{mg}, 0.5 \mathrm{mmol})$ were stirred in 10 $\mathrm{mL}$ of ODCB. The reaction mixture was heated at $140{ }^{\circ} \mathrm{C}$ until complete disappearance of porphyrin 4 by TLC monitoring. The reaction mixture was purified on a silica gel column using dichloromethane/ethyl acetate for elution. The main fraction was collected, recrystallized from chloroform/hexane and dried under vacuum to yield the title porphyrin (26.6 mg, 73\%). HRMALDI-TOF-MS for $\mathrm{C}_{52} \mathrm{H}_{103} \mathrm{~N}_{4} \mathrm{O}_{2} \mathrm{~B}_{36} \mathrm{Co}_{4} \mathrm{Na}_{2}: \mathrm{m} / 2$ calcd, 1401.0078 $[\mathrm{M}+\mathrm{Na}]^{+}$, found $1401.0092 .{ }^{1} \mathrm{H}-\mathrm{NMR}\left(\right.$ acetone- $\left.\mathrm{d}_{6}\right): 11.38(\mathrm{~s}, 1 \mathrm{H}, \mathrm{meso}-\mathrm{H}), 11.33(\mathrm{~s}, 2 \mathrm{H}$, meso-H), 11.09 (s, 1H, meso-H), 3.93-4.36 (m, $16 \mathrm{H}, \mathrm{CH}_{2}$ ), 3.81 (brs, $4 \mathrm{H}$, car- $\left.\mathrm{H}\right), 3.38$ (brs, $4 \mathrm{H}$, car- $\mathrm{H}), 2.85\left(\mathrm{~m}, 4 \mathrm{H}, \mathrm{OCH}_{2}\right), 2.36$ (brs, $\left.4 \mathrm{H}, \mathrm{OCH}_{2}\right), 1.85-1.88\left(\mathrm{~m}, 12 \mathrm{H}, \mathrm{CH}_{3}\right), 1.44-1.56$ (m, 6H, $\mathrm{CH}_{3}$ ), 1.27-1.42 (m, 6H, $\left.\mathrm{CH}_{3}\right), 0.12$ (brs, $4 \mathrm{H}, \mathrm{OCH}_{2}$ ), 0.1-4.0 (br, 34H, BH), 5.41--5.35 (m, 2H, NCH$),-6.44-6.38\left(\mathrm{~m}, 2 \mathrm{H}, \mathrm{NCH}_{2}\right)$. UV-Vis (acetone) $\lambda_{\max }(\mathrm{nm}) 427(\varepsilon$ $141,500), 573(9,800), 617(5,300)$.

\section{5-(N-Cobaltacarboranephenyl)-10,15,20-triphenylporphyrin (8) and 5-(N,N- dicobaltacarboranephenyl)-10,15,20-triphenylporphyrin (9)}

Aminoporphyrin 7 (33.0 mg, $0.05 \mathrm{mmol})$ and $\left[3,3^{\prime}-\mathrm{Co}\left(8-\mathrm{C}_{4} \mathrm{H}_{8} \mathrm{O}_{2}-1,2-\mathrm{C}_{2} \mathrm{~B}_{9} \mathrm{H}_{10}\left(1^{\prime}, 2^{\prime}-\right.\right.\right.$

$\left.\left.\mathrm{C}_{2} \mathrm{~B}_{9} \mathrm{H}_{10}\right)\right](41.0 \mathrm{mg}, 0.1 \mathrm{mmol})$ were dissolved in a mixture of $2.5 \mathrm{~mL} \mathrm{CHCl}_{3}$ and $5 \mathrm{~mL}$ $\mathrm{CH}_{3} \mathrm{CN}$. The reaction mixture was left refluxing overnight. The crude product was purified on a silica gel column using chloroform/ethyl acetate for elution, giving two major fractions $\mathbf{8}$ and $\mathbf{9}$ which were recrystallized from chloroform/hexane and dried under vacuum. Porphyrin 8 was obtained in $46 \%$ yield $(25.7 \mathrm{mg}$ ). HR-MALDI-TOF-MS for $\mathrm{C}_{52} \mathrm{H}_{59} \mathrm{~N}_{5} \mathrm{O}_{2} \mathrm{~B}_{18} \mathrm{Co}_{2} \mathrm{Na}: \mathrm{m} / z$ calcd, $1063.5794[\mathrm{M}+\mathrm{H}]^{+}$, found $1063.5802 ; \mathrm{m} / \mathrm{z}$ calcd $1039.5818[\mathrm{M}-\mathrm{Na}]^{-}$, found $1039.5863 .{ }^{1} \mathrm{H}-\mathrm{NMR}$ (acetone- $\left.\mathrm{d}_{6}\right): 9.02(\mathrm{~d}, 2 \mathrm{H}, \beta-\mathrm{H}), 8.83(\mathrm{~m}$, $6 \mathrm{H}, \beta-\mathrm{H}), 8.22$ (m, 6H, o-phenyl-H), 7.95 (d, 2H, o-Ar-H), 7.81 (m, 9H, m,p-phenyl-H), 
7.07(d, 2H, p-Ar-H), $5.23(\mathrm{~b}, 1 \mathrm{H}, \mathrm{NH}), 4.38\left(\mathrm{~s}, 2 \mathrm{H}, \mathrm{OCH}_{2}\right), 4.31\left(\mathrm{~s}, 2 \mathrm{H}, \mathrm{OCH}_{2}\right), 3.83(\mathrm{t}, 2 \mathrm{H}$, $\left.\mathrm{OCH}_{2}\right), 3.66(\mathrm{~m}, 4 \mathrm{H}, \mathrm{car}-\mathrm{H}), 3.50\left(\mathrm{t}, 2 \mathrm{H}, \mathrm{NCH}_{2}\right), 1.6-3.0(\mathrm{br}, 17 \mathrm{H}, \mathrm{BH}),-2.67(\mathrm{~s}, 2 \mathrm{H}$, $\mathrm{NH}) .{ }^{13} \mathrm{C}$ NMR (acetone- $\mathrm{d}_{6}$ ) 149.6, 142.9, 142.8, 136.4, 135.1, 130.3, 128.6, 127.6, 122.7, $120.7,120.2,111.8,72.6,70.2,69.2,55.3,47.2,44.2$. UV-vis (acetone) $\lambda_{\max }(\mathrm{nm}) 415$ ( $\varepsilon$ 242,200), 515 (15,900), $555(11,600), 589(6,600), 651$ (5,600). Porphyrin 9 was obtained in $26 \%$ (20.4 mg) yield. HR-MALDI-TOF-MS for $\mathrm{C}_{60} \mathrm{H}_{87} \mathrm{~N}_{5} \mathrm{O}_{4} \mathrm{~B}_{36} \mathrm{Co}_{2} \mathrm{Na}_{2}: \mathrm{m} / z$ calcd, $1498.8910[\mathrm{M}+\mathrm{H}]^{+}$, found $1496.9001 ; \mathrm{m} / z$ calcd, $1472.8933[\mathrm{M}-\mathrm{Na}]^{-}$, found 1472.8957. ${ }^{1} \mathrm{H}-\mathrm{NMR}$ (acetone- $\left.\mathrm{d}_{6}\right)$ : $9.08(\mathrm{~d}, 2 \mathrm{H}, \beta-\mathrm{H}), 8.84(\mathrm{~m}, 6 \mathrm{H}, \beta-\mathrm{H}), 8.23(\mathrm{~m}, 6 \mathrm{H}, \mathrm{o}-$ phenyl-H), 8.08 (d, 2H, o-Ar-H), 7.80 (m, 9H, m,p-phenyl-H), 7.26(d, 2H, p-Ar-H), 4.42 (br, $4 \mathrm{H}, \mathrm{OCH}_{2}$ ), 4.30 (br, $8 \mathrm{H}, \mathrm{OCH}_{2}$ ), 3.90 (br, $8 \mathrm{H}, \mathrm{OCH}_{2}$ ), 3.70 (br, 8H, car-H), 1.6-3.0 (br, $34 \mathrm{H}, \mathrm{BH}),-2.60$ (s, 2H, NH). ${ }^{13} \mathrm{C}-\mathrm{NMR}$ (acetone- $\left.\mathrm{d}_{6}\right)$ 148.6, 142.7, 136.5, 135.0, 134.9, $129.5,128.4,127.4,122.6,120.5,120.0,111.1,72.7,69.0,68.9,55.3,51.6,47.0$. UV-vis (acetone) $\lambda_{\max }(\mathrm{nm}) 413$ ( 2222,600$), 516(15,800), 559(13,000), 591(7,900), 651(6,300)$.

\section{RESULTS}

\section{Synthesis}

The synthesis of zwitterionic cobaltacarborane $\left[3,3^{\prime}-\mathrm{Co}\left(8-\mathrm{C}_{4} \mathrm{H}_{8} \mathrm{O}_{2}-1,2-\mathrm{C}_{2} \mathrm{~B}_{9} \mathrm{H}_{10}\left(1^{\prime}, 2^{\prime}-\right.\right.\right.$ $\mathrm{C}_{2} \mathrm{~B}_{9} \mathrm{H}_{10}$ )] was first reported in 1997 (26) and then modified by Teixidor et al (27). Upon refluxing the cobaltabisdicarbollide anion $\left[\mathrm{Co}\left(\mathrm{C}_{2} \mathrm{~B}_{9} \mathrm{H}_{11}\right)_{2}\right]^{-}$in 1,4-dioxane in the presence of $\mathrm{BF}_{3} \cdot \mathrm{Et}_{2} \mathrm{O},\left[3,3^{\prime}-\mathrm{Co}\left(8-\mathrm{C}_{4} \mathrm{H}_{8} \mathrm{O}_{2}-1,2-\mathrm{C}_{2} \mathrm{~B}_{9} \mathrm{H}_{10}\left(1^{\prime}, 2^{\prime}-\mathrm{C}_{2} \mathrm{~B}_{9} \mathrm{H}_{10}\right)\right]\right.$ was isolated in $80 \%$ yield, along with a slightly less polar minor fraction of $\left[8,8^{\prime}-\mu-\left(\mathrm{C}_{2} \mathrm{H}_{5} \mathrm{O}\right)-3,3^{\prime}-\mathrm{Co}\left(1,2-\mathrm{C}_{2} \mathrm{~B}_{9} \mathrm{H}_{10}\right)_{2}\right]$ in $4 \%$ yield. The structure of this minor fraction was confirmed by X-ray crystallography (see Supporting Information, Figure $\mathrm{S} 1)$. The cobaltacarborane $\left[8,8^{\prime}-\mu-\left(\mathrm{C}_{2} \mathrm{H}_{5} \mathrm{O}\right)-3,3^{\prime}-\mathrm{Co}(1,2-\right.$ $\left.\left.\mathrm{C}_{2} \mathrm{~B}_{9} \mathrm{H}_{10}\right)_{2}\right]$ has been previously synthesized in low yield $(5 \%)$ from $\left[\mathrm{Co}\left(\mathrm{C}_{2} \mathrm{~B}_{9} \mathrm{H}_{11}\right)_{2}\right]^{-}$, by refluxing in acetic anhydride in the presence of sulfuric acid (28). The structure of $\left[8,8^{\prime}-\mu\right.$ $\left.\left(\mathrm{C}_{2} \mathrm{H}_{5} \mathrm{O}\right)-3,3^{\prime}-\mathrm{Co}\left(1,2-\mathrm{C}_{2} \mathrm{~B}_{9} \mathrm{H}_{10}\right)_{2}\right]$ is similar to the known methyloxonium derivative [8,8'$\left.\mu-\left(\mathrm{CH}_{3} \mathrm{O}\right)-3,3^{\prime}-\mathrm{Co}\left(1,2-\mathrm{C}_{2} \mathrm{~B}_{9} \mathrm{H}_{10}\right)_{2}\right](29)$ in that the $\mathrm{C}_{2} \mathrm{~B}_{3}$ pentagonal planes bound to the cobalt atom are non-parallel due to the short oxygen bridge (mean $\mathrm{B}-\mathrm{O}=1.517(2) \AA$, $\mathrm{B}-\mathrm{O}-$ $\left.\mathrm{B}=95.41(11)^{\circ}\right)$, forming a dihedral angle of $26.48(10)^{\circ}$.

The reaction of metal-free $\mathrm{H}_{2} \mathrm{TPP}(\mathbf{1})$ or $\mathrm{H}_{2} \mathrm{OEP}$ (2) with [3,3'-Co(8- $\mathrm{C}_{4} \mathrm{H}_{8} \mathrm{O}_{2}-1,2$ $\left.\mathrm{C}_{2} \mathrm{~B}_{9} \mathrm{H}_{10}\left(1^{\prime}, 2^{\prime}-\mathrm{C}_{2} \mathrm{~B}_{9} \mathrm{H}_{10}\right)\right]$ in refluxing ODCB yielded the corresponding mono-substituted $\mathrm{N}$-cobaltacarborane porphyrins $\mathbf{3}$ and $\mathbf{4}$, in 81 and $89 \%$ yield, respectively (Scheme 1). Similar yields were obtained using chloroform as the solvent in the presence of $\mathrm{NaHCO}_{3}$, but the reaction took 10 days for completion, instead of 2 hours in ODCB. Small amounts of the di-substituted derivatives 5 or $\mathbf{6}(1-5 \%)$ were also isolated under the above reaction conditions. Higher yields (73-83\%) of the $\mathrm{N}, \mathrm{N}$-dicobaltacarborane porphyrins were obtained upon reaction of the mono-substituted derivatives 3 or 4 with [3,3'- $\mathrm{Co}\left(8-\mathrm{C}_{4} \mathrm{H}_{8} \mathrm{O}_{2}-1,2-\right.$ $\left.\mathrm{C}_{2} \mathrm{~B}_{9} \mathrm{H}_{10}\left(1^{\prime}, 2^{\prime}-\mathrm{C}_{2} \mathrm{~B}_{9} \mathrm{H}_{10}\right)\right]$ in refluxing ODCB and in the presence of a base $\left(\mathrm{NaHCO}_{3}\right)$. Porphyrins 3 - 6 are highly basic and were isolated in their core-protonated forms. On the other hand, mono-aminoporphyrin 7 (23) reacted with $\left[3,3^{\prime}-\mathrm{Co}\left(8-\mathrm{C}_{4} \mathrm{H}_{8} \mathrm{O}_{2}-1,2-\mathrm{C}_{2} \mathrm{~B}_{9} \mathrm{H}_{10}\left(1^{\prime}\right.\right.\right.$, $\left.\left.2^{\prime}-\mathrm{C}_{2} \mathrm{~B}_{9} \mathrm{H}_{10}\right)\right]$ in a mixture of chloform and acetonitrile $(\mathrm{v} / \mathrm{v}=1 / 2)$ to produce the $N$ substituted derivatives 8 and $\mathbf{9}$ in $46 \%$ and $26 \%$ yields, respectively (Scheme 2).

The structures of porphyrins $3-6,8$ and 9 were confirmed by HRMS, NMR and, in the case of $\mathbf{3}$ and $\mathbf{4}$, by single crystal X-ray crystallography (Figures 1-6). The molecular structures of porphyrins $\mathbf{3}$ and $\mathbf{4}$, shown in Figures 1 and 2, respectively, are rare examples of singly protonated $N$-substituted porphyrins. The crystal of porphyrin $\mathbf{3}$ was grown from pyridine/ cyclohexane and the two inner porphyrin NHs form hydrogen bonds with one water molecule, which also forms two additional hydrogen bonds with two solvent pyridine molecules, as seen in Figure 1. On the other hand, the crystal of porphyrin $\mathbf{4}$ was grown from dichloromethane/methanol and this molecule is less distorted from planarity than $\mathbf{3}$, as 
shown in Figure 2. The NMR spectra confirmed the proposed structures for porphyrins 3 $\mathbf{6}, \mathbf{8}$ and 9 , and confirmed the remarkable regioselective in the formation of di- $N, N-$ substituted porphyrins $\mathbf{5}$ and $\mathbf{6}$. The UV-Vis and fluorescence spectra are also consistent with the assigned structures.

\section{Electrochemistry and Spectroelectrochemistry}

Two types of electrochemical behavior are obtained, one for conjugates 3-6 where the porphyrin-cobaltabisdicarbollide linkage is at one or two of the four central porphyrins nitrogens (Scheme 1) and the other for conjugates $\mathbf{8}$ and $\mathbf{9}$ which are linked at a single meso position of the macrocycle as seen in Scheme 2. Cyclic voltammograms for reduction and oxidation of the six conjugates are shown in Figure 7 and 8, but are well-defined only in the case of compounds 8 and 9 (Figure 7); compounds 3-6 exhibit irreversible processes due to coupled chemical reactions which occur during or after electron transfer and this leads to the more complicated cyclic voltammograms (Figure 8). A summary of peak potentials for all of the investigated compounds in $\mathrm{PhCN}$ is given in Table 1.

In order to investigate the site of electron transfer, the reduced and oxidized forms of the conjugates were monitored by thin-layer spectroelectrochemistry. Examples of the spectral changes during the oxidation and reduction are shown in Figures 9-12 and a summary of the $\mathrm{UV}$-visible data is given in Table 2 which includes $\mathrm{H}_{2} \mathrm{TPP}$ for comparison.

\section{DISCUSSION}

In the absence of a nucleophilic group at the macrocycle periphery, metal-free porphyrins $\mathrm{H}_{2} \mathrm{TPP}(\mathbf{1})$ and $\mathrm{H}_{2} \mathrm{OEP}(2)$ reacted with zwitterionic [3,3'- $\mathrm{Co}\left(8-\mathrm{C}_{4} \mathrm{H}_{8} \mathrm{O}_{2}-1,2-\mathrm{C}_{2} \mathrm{~B}_{9} \mathrm{H}_{10}\right)\left(1^{\prime}, 2^{\prime}-\right.$ $\left.\mathrm{C}_{2} \mathrm{~B}_{9} \mathrm{H}_{10}\right)$ ] to give the corresponding mono- $N$ - (3 and $\left.\mathbf{4}\right)$ and di-adj- $(\mathbf{5}$ and $\mathbf{6}) N, N$ cobaltacarboranyl porphyrins, in their core-protonated forms, in high yields. On the other hand, in agreement with our previous reports showing that free-base porphyrins containing one or multiple nucleophilic groups (hydroxy, pyridyl, phenol) at the macrocycle periphery react with $\left[3,3^{\prime}-\mathrm{Co}\left(8-\mathrm{C}_{4} \mathrm{H}_{8} \mathrm{O}_{2}-1,2-\mathrm{C}_{2} \mathrm{~B}_{9} \mathrm{H}_{10}\right)\left(1^{\prime}, 2^{\prime}-\mathrm{C}_{2} \mathrm{~B}_{9} \mathrm{H}_{10}\right)\right]$ preferentially at these sites (21), mono-aminoporphyrin 7 produced the $N$-substituted derivatives 8 and 9 in low to moderate yields, probably due to steric hindrance and the low nucleophilicity of the amino group.

The spectroscopic properties of the new $N$-cobaltacarborane porphyrin conjugates were investigated and two X-ray structures of the mono- $N$-cobaltacarborane porphyrins $\mathbf{3}$ and $\mathbf{4}$ were obtained, which show the different degrees of distortion from planarity in these molecules. In the molecular structure of porphyrin 3 (Figure 1) the two protonated pyrrolenic rings are located adjacent to the alkylated ring and are rotated in the opposite sense. Since there is a negative charge on the cobaltacarborane moiety, this molecule is zwitterionic. On the other hand, the structure of porphyrin 4 (Figure 2) is less distorted from planarity than the corresponding $\mathrm{H}_{2}$ TPP derivative 3 , most likely because of the lack of hydrogen bonding to a water molecule, as exists in $\mathbf{3}$, and perhaps lower steric hindrance of the pyrrolic ethyl groups of $\mathrm{H}_{2} \mathrm{OEP}$ compared with the meso-phenyl groups of $\mathrm{H}_{2} \mathrm{TPP}$ (30). In 4 , the porphyrin $N$ atom carrying the cobaltacarborane substituent lies 0.371(4) $\AA$ out of the plane of the other three $N$ atoms, and the cobaltacarborane-carrying pyrrole ring forms a dihedral angle of $17.2(5)^{\circ}$ with the plane of the other 19 atoms in the porphyrin ring. This is quite similar to the conformation found in the analogous compound in which the substituted $N$ atom carries an ethoxycarbonylmethyl group (31), where the dihedral angle is $19.1^{\circ}$ and the substituted $N$ atom lies $0.28 \AA$ out of the $N_{3}$ plane. In that structure, there is also a lack of intermolecular hydrogen bonding involving the porphyrin $N$ atoms. 
The ${ }^{1} \mathrm{H}$-NMR of porphyrin 3 shows the $\mathrm{NCH}_{2}$ signals at $-4.83 \mathrm{ppm}$, in agreement with data reported for $N$-methyl-TPP (12), while the $\mathrm{NCH}_{2}$ signals for porphyrin 4 appear at -5.57 $\mathrm{ppm}$. The ${ }^{1} \mathrm{H}$-NMR spectrum of porphyrin $\mathbf{4}$ also shows two singlet resonances for the four meso-protons at 10.67 and $10.61 \mathrm{ppm}$, which are split into two signals of the same intensity (1:1). In contrast, the ${ }^{1} \mathrm{H}-\mathrm{NMR}$ spectrum of the di-substituted porphyrin 5 gave two different $N \mathrm{NH}_{2}$ peaks at $-5.80 \mathrm{ppm}$ and $-4.25 \mathrm{ppm}$, and one $N \mathrm{H}$ peak at $-2.64 \mathrm{ppm}$. The ${ }^{1} \mathrm{H}-{ }^{1} \mathrm{H}$ COSY NMR spectrum for porphyrin 5 shows that the two hydrogen atoms of the $\mathrm{NCH}_{2}$ are in the different environments and therefore generate the two observed peaks at $-5.80 \mathrm{ppm}$ and $-4.25 \mathrm{ppm}$. The symmetry observed in the ${ }^{1} \mathrm{H}$ - and ${ }^{13} \mathrm{C}-\mathrm{NMR}$ spectra of porphyrin 5 indicates that the two alkylated nitrogen atoms are adjacent to each other (Figure $3 \mathrm{a}$ ). The eight $\beta$-protons are split into 2:4:2, suggesting adjacent $N$-substitution. Similarly, the ${ }^{1} \mathrm{H}$ NMR spectrum of porphyrin 6 shows three resonances for the meso-protons, split into 1:2:1 (Figure $3 b$ ), which further indicates that the two substituents are on adjacent nitrogen atoms. Porphyrins $\mathbf{5}$ and $\mathbf{6}$ were isolated as the monocations due to the strong basicity of the corresponding free-bases. Their remarkable regioselective formation has been previously observed in $N$-alkylation reactions (30-37). The $N$-methylations of $\mathrm{H}_{2}$ TPP and $\mathrm{H}_{2} \mathrm{OEP}$ using a variety of methylation reagents are reported to give adjacent $N, N$-dimethyl derivatives due to attack from the less sterically hindered side of the mono- $N$-methylated derivative. The regioselectivity of this reaction has been confirmed by X-ray structures in both cases $(30,35)$.

$\mathrm{N}$-Substitution is known to increase the degree of nonplanarity of the porphyrin macrocycle and as a consequence bathochromic shifts are usually observed in the optical spectra of $N$ substituted porphyrins, which correlate with the degree of conformation distortion (5). Significant red-shifts (15-32 nm) in the Soret bands of porphyrins $3-6$ were observed (Figures 4, 5), in comparison with the starting porphyrins $\mathrm{H}_{2}$ TPP $\mathbf{1}$ and $\mathrm{H}_{2} \mathrm{OEP} \mathbf{2}$, as well as with the meso-substituted porphyrins $\mathbf{8}$ and $\mathbf{9}$ (see Supporting Information, Figures S2 and $\mathrm{S} 3$ ), which result from the distortion of the porphyrin macrocycle upon $N$-substitution. The fluorescence emission spectra of porphyrins 3 - 6 (Figure 6) show nearly complete fluorescence quenching for all $N$-substituted porphyrins (more than $90 \%$ as compared with starting porphyrins $\mathbf{1}$ and $\mathbf{2}$ ) and this is due to strong distortions of the porphyrin planar conformation by the cobaltocarboranes attached to the central nitrogen atom(s). On the other hand, $N$-substituted porphyrins $\mathbf{8}$ and $\mathbf{9}$ showed similar spectroscopic data to the starting aminoporphyrin, since in these compounds there is no significant distortion of the porphyrin macrocycle.

\section{Electrochemistry}

The unlinked cobaltbisdicarbollide undergoes two reversible metal-centered reactions (38) at $\mathrm{E}_{1 / 2}=-1.34 \mathrm{~V}\left(\mathrm{Co}^{\mathrm{III} / \mathrm{II}}\right)$ and $1.65 \mathrm{~V}\left(\mathrm{Co}^{\mathrm{III} / \mathrm{IV}}\right)$ while the unlinked free-base porphyrin

$\mathrm{H}_{2} \mathrm{TPP} 1$, displays four reversible reactions, two oxidations and two reductions (39).

Conjugates 8 and $\mathbf{9}$ are characterized by six electron transfer processes, four of which are assigned to the porphyrin part of the molecule and two to the cobalt center of the cobaltabisdicarbollide. The cobalt-centered reactions of $\mathbf{8}$ and $\mathbf{9}$ occur at $\mathrm{E}_{1 / 2}=-1.35$ to $-1.37 \mathrm{~V}$ for reduction and $\mathrm{E}_{\mathrm{p}}=1.62$ to $1.64 \mathrm{~V}$ for oxidation at a scan rate of $0.1 \mathrm{~V} / \mathrm{s}$, and are at virtually identical potentials as for reduction and oxidation of unlinked cabaltabisdicarbollide under the same solution conditions (see dashed lines in Figure 7).

As indicated above, $\mathrm{H}_{2} \mathrm{TPP}$ undergoes two reversible one electron oxidations (at $\mathrm{E}_{1 / 2}=1.05$ and $1.33 \mathrm{~V})$ and two one-electron oxidations are also seen for conjugate $8(0.83$ and $0.96 \mathrm{~V})$ and $9(0.78$ and $0.93 \mathrm{~V})$. The easier oxidations of 8 and 9 as compared to $\mathrm{H}_{2} \mathrm{TPP}$ result from the electron-donating substituent $\mathrm{PhNR}_{2}$ at one meso-position of the porphyrin macrocycle. Easier oxidations have also been reported for porphyrins containing $\mathrm{PhNR}_{2}$ substituents at all four-meso positions of a tetraphenylporphyrin macrocycle (42-44). The difference in 
potential between the first oxidation of $\mathrm{H}_{2}$ TPP and the first oxidation of conjugate $\mathbf{8}$ is 220 $\mathrm{mV}$ while the difference in $\mathrm{E}_{1 / 2}$ value between the second oxidation of the two compounds is $370 \mathrm{mV}$. A further negative shift in $\mathrm{E}_{1 / 2}$ of $30-50 \mathrm{mV}$ is then seen upon going from conjugate 8 to conjugate 9 in PhCN, 0.1 M TBAP.

The two reversible reductions of $\mathrm{H}_{2} \mathrm{TPP}$ at $\mathrm{E}_{1 / 2}=-1.15$ and $-1.54 \mathrm{~V}$ can be compared to similar electroreduction potentials for conjugate 8 at -1.20 and $-1.56 \mathrm{~V}$ and conjugate 9 at -1.22 and $-1.58 \mathrm{~V}$ (Figure 7). Here the two conjugates are only $10-20 \mathrm{mV}$ harder to reduce than $\mathrm{H}_{2}$ TPP. This lack of a substantial substituent effect on reductions is consistent with what has been observed in the literature for tetraphenylporphyrins with four $\mathrm{PhNR}_{2}$ as meso substituents (42-44).

The reversible reduction potentials of porphyrin 8 at $-1.35 \mathrm{~V}$ and porphyrin 9 at $-1.37 \mathrm{~V}$ are unambiguously assigned to the $\mathrm{Co}$ III/ $\mathrm{Co}^{\mathrm{II}}$ processes of the linked cobaltabisdicarbollide. The peak current for reduction of the unlinked cobaltabisdicabollide and $\mathbf{8}$ are about equal in $\mathrm{PhCN}$, consistent with one electron being transferred in each case. These contrasts with what is seen for reduction of 9 where the peak current of the $\mathrm{Co}^{\mathrm{III} / \mathrm{II}}$ process is approximately double that of $\mathbf{8}$, consistent the addition of two electrons, one to each electroactive cobaltabisdicarbollide group on the compound. Changing the number of cobaltabisdicarbollide groups from one to two does not affect the values of $\mathrm{E}_{1 / 2}$ suggesting that no interaction occurs between these two redox centers in conjugate 9 .

A summary of peak potentials for all of the investigated compounds in $\mathrm{PhCN}$ is given in Table 1. The reduction of $\mathbf{8}$ and $\mathbf{9}$ first proceeds via a one-electron addition to the porphyrin macrocycle giving a $\pi$-anion radical, after which one electron is added to each cobaltabisdicarbollide unit at a more negative potential of -1.35 to $-1.37 \mathrm{~V}$. Further reduction at the porphyrin macrocycle then occurs at $\mathrm{E}_{1 / 2}=-1.56$ to $-1.58 \mathrm{~V}$ as shown in Figure 7. This reduction mechanism is shown graphically in Scheme 3 which also includes data for the oxidations. In this case, the first two one-electron abstractions from 8 or $9\left(\mathrm{E}_{1 / 2}\right.$ $=0.78$ to $0.96 \mathrm{~V}$ ) involve the porphyrin part of the molecule and the third electron abstraction involves the cobalt center of the cobaltabisdicarbollide. Additional proof for these assignments is given by spectroelectrochemical data described on the following pages.

Because irreversible chemical reactions are coupled to the electron transfers of 3-6, attempts to assign a mechanism of electron transfer are tenuous at best and this is made more difficult by the fact that compounds 3 to $\mathbf{6}$ have not only different core porphyrin structures $\left(\mathrm{H}_{2} \mathrm{TPP}\right.$ vs. $\mathrm{H}_{2} \mathrm{OEP}$ ) but also differ in the number of linked cobaltabisdicarbollide groups ( 1 or 2 ) on the central nitrogen atoms. Nonetheless, several comparisons can be made from the currentvoltage curves in Figure 8. The first is that $\mathbf{3}$ and $\mathbf{4}$, which have a single linked $\mathrm{N}$-substituted cobaltabisdicarbollide group, both show current-voltage curves characteristic of a chemical reaction following electron transfer (an electrochemical EC mechanism). The peak potential for the first reduction of 3 is located at $E_{p}=-0.49 \mathrm{~V}$ for a scan rate of $0.1 \mathrm{~V} / \mathrm{s}$ while the $E_{p}$ of 4 is located at $-0.76 \mathrm{~V}$ under the same experimental conditions. This $270 \mathrm{mV}$ difference in peak potential between $E_{p}$ for reduction of $\mathbf{3}$ and $\mathbf{4}$, is similar in magnitude to potential separations for reductions of many metalloporphyrins with $\mathrm{H}_{2} \mathrm{OEP}$ and $\mathrm{H}_{2} \mathrm{TPP}$ core structures where the $\mathrm{H}_{2} \mathrm{TPP}$ derivatives are always easier to reduce $(39,40,41)$. In fact, the $280 \mathrm{mV}$ difference in $\mathrm{E}_{1 / 2}$ between the first reduction of $\mathrm{H}_{2} \mathrm{TPP}(-1.15 \mathrm{~V}$ vs SCE) and $\mathrm{H}_{2} \mathrm{OEP}(-1.43 \mathrm{~V})$ in PhCN, 0.1 M TBAP, is experimentally the same as the $\Delta \mathrm{E}_{\mathrm{p}}$ value between the first reduction of $\mathbf{3}$ and $\mathbf{4}$ under the same solution conditions.

One can also compare the $E_{p}$ values for reduction of 3 and $\mathbf{4}$ to $E_{1 / 2}$ values for reduction of $\mathrm{H}_{2} \mathrm{TPP}$ or $\mathrm{H}_{2} \mathrm{OEP}$ (see references $42-43$ and voltammograms of free-base porphyrins in 
Figure S4). Conjugate $3\left(E_{p}=-0.49 \mathrm{~V}\right)$ is $660 \mathrm{mV}$ easier to reduce than $\mathrm{H}_{2} \mathrm{TPP}\left(\mathrm{E}_{1 / 2}=\right.$ $-1.15 \mathrm{~V})$ while conjugate $4(-0.76 \mathrm{~V})$ is $670 \mathrm{mV}$ easier to reduce than $\mathrm{H}_{2} \mathrm{OEP}(-1.43 \mathrm{~V})$.

Altogether three reductions are seen for conjugate 3 in PhCN containing 0.1 M TBAP. As mentioned above, the first is irreversible and occurs at $\mathrm{E}_{\mathrm{p}}=-0.49 \mathrm{~V}$. The next two reductions are located at $\mathrm{E}_{\mathrm{p}}=-1.17 \mathrm{~V}$ and $\mathrm{E}_{1 / 2}=-1.38 \mathrm{~V}$ and are similar to processes also seen for conjugate $\mathbf{5}$. This might suggest that the cobaltabisdicarbollide group dissociates from the porphyrin after the first electron transfer in $\mathbf{5}$. The measured redox potentials observed for reaction of the cobalt groups in the $\mathrm{H}_{2} \mathrm{TPP}$ based conjugates $(-1.38$ and $1.60 \mathrm{~V}$ for 3 and -1.40 and $1.57 \mathrm{~V}$ for 5 ) are similar to $\mathrm{E}_{1 / 2}$ values for the unlinked comparison compound $(-1.34$ and $1.65 \mathrm{~V})$, and this suggests that in the ground state there is only weak electronic interactions between porphyrin and cobaltabisdicarbollide group within the conjugate.

Irreversible oxidation processes are observed at $1.39 \mathrm{~V}$ and $1.64 \mathrm{~V}$ for conjugates $\mathbf{4}$ and $\mathbf{6}$, respectively. Two reduction processes are observed at $\mathrm{E}_{\mathrm{p}}=-0.76$ and $\mathrm{E}_{1 / 2}=-1.39 \mathrm{~V}$ in conjugate 4, while conjugate 6 undergoes several irreversible reduction processes, and one reversible reduction at $\mathrm{E}_{1 / 2}=-1.39 \mathrm{~V}$. Comparison of these values with redox potentials of octaethylporphyrin $\left(\mathrm{H}_{2} \mathrm{OEP}\right)$, leads to the conclusion the reduction at $\mathrm{E}_{1 / 2}=-1.39 \mathrm{~V}$ occurs at $\mathrm{Co}(\mathrm{III})$ center of the cobaltabisdicarbollide group and the oxidation at $\mathrm{E}_{\mathrm{p}}=1.39 \mathrm{~V}$ occurs at porphyrin macrocycle.

The $N$-cobaltacarboranyl porphyrins $\mathbf{8}$ and $\mathbf{9}$ undergo three reversible reductions, two of which are assigned to porphyrin macrocycle reactions and one is characterized by $\mathrm{Co}^{\mathrm{III}}$ to $\mathrm{Co}{ }^{\mathrm{II}}$. They also have two reversible porphyrin ring-centered oxidations and one irriversible

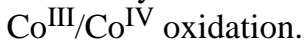

The core $N$-substituted porphyrins exhibit complicated electrochemical behavior with coupled chemical reactions. However, the cobalt centered reaction site could be assigned by comparison for the $\mathrm{E}_{1 / 2}$ of the unlinked cobaltabisdicarbollide.

\section{Spectroelectrochemistry}

When the intensity of a porphyrin Soret band significantly decreases after a reduction or oxidation, the electron transfer site is generally porphyrin ring-centered, leading to the formation of a $\pi$-anion or $\pi$-cation radical (39-41). However, when the Soret band is only slightly shifted in wavelength and undergoes little or no change in molar absorptivity upon reduction or oxidation, the electron-transfer site can often be assigned as the metal-centered. Thus, comparisons between the observed spectral changes during oxidation or reduction of the conjugates with spectral changes obtained during oxidation or reduction of $\mathrm{H}_{2} \mathrm{TPP}$ and $\mathrm{H}_{2} \mathrm{OEP}$, may shed light on the probable site of electron transfer in the investigated compounds.

The changes in spectra during oxidations of conjugate $\mathbf{8}$ are shown in Figure 9. As the oxidation proceeds, the original Soret band at $424 \mathrm{~nm}$ decreases in intensity and shifts to 433 $\mathrm{nm}$ and a new band grows at $716 \mathrm{~nm}$. These changes are consistent with formation of a porphyrin $\pi$-cation radical during the first electron abstraction. In the second oxidation process, a new intense Soret band grows in $444 \mathrm{~nm}$ and a well-defined visible band at 666 $\mathrm{nm}$ is also observed. Similar spectral changes are observed during the two oxidations of $\mathrm{H}_{2} \mathrm{TPP}$ in PhCN, 0.2 M TBAP (Supporting Information, Figure S4).

The UV-visible spectral evolution upon the first one-electron reduction of $\mathbf{8}$ or $\mathbf{9}$ are also similar to spectral changes upon reduction of $\mathrm{H}_{2}$ TPP (Table 2) and are assigned to reactions occurring at the conjugated $\pi$-ring system of the porphyrin. During reductions of conjugates 
8 and $\mathbf{9}$, the Soret band decreases in intensity and a new Soret band is seen at $455-488 \mathrm{~nm}$ together with a broad band between $600-900 \mathrm{~nm}$, which can be interpreted as formation of a porphyrin $\pi$-anion radical. The second reduction of $\mathbf{8}$ and $\mathbf{9}$ occurs at the linked cobaltabisdicarbollide. As $\mathrm{Co}^{\mathrm{II}}$ is formed, there is a decreased intensity of the band at about $314 \mathrm{~nm}$ (characteristic of $\mathrm{Co}^{\mathrm{III}}$ ), and an increased intensity of the absorption at the $348 \mathrm{~nm}$ band which is assigned to $\mathrm{Co}^{\mathrm{II}}$.

In the case of the $\mathrm{N}$-substituted conjugates, an assignment of the electron transfer site is less clear. As seen in Figure 10, the spectral evolution of $\mathbf{3}$ during the first reduction shows a blue shift of the Soret band from $441 \mathrm{~nm}$ (Soret band of $\mathrm{H}_{2} \mathrm{TPP}$ ) to $436 \mathrm{~nm}$. The UV-visible spectrum of the singly reduced conjugate looks similar to that of neutral $\mathrm{H}_{2} \mathrm{TPP}$, thus suggesting loss of the cobaltabisdicarbollide group after the first reduction.

In the case of conjugates $\mathbf{4}$ and $\mathbf{6}$, comparisons may be made with spectral changes during the reduction or oxidation of $\mathrm{H}_{2} \mathrm{OEP}$. When a potential of $-0.90 \mathrm{~V}$ to $\mathbf{4}$ or $\mathbf{6}$ is applied, a similar evolution of the spectra is seen (Figure 11) and the final spectra can be interpreted in terms of porphyrin $\pi$ anion radical formation. The second reduction involves two steps for these two conjugates, and here the electron transfer may occur at both the porphyrin $\pi$-ring system and the metal center of the cobaltabisdicarbollide group.

For conjugate 6 (Figure 12), a two-step electron transfer occurs during the first oxidation. The intensity of Soret band at $417 \mathrm{~nm}$ decreases and a new band grows at $428 \mathrm{~nm}$. No spectral changes are observed at $317 \mathrm{~nm}$, suggesting that the electron-transfer in this step occurs at the porphyrin $\pi$-ring system. The Soret band at $428 \mathrm{~nm}$ disappears during the second step electron transfer, as the intensity of the band at $317 \mathrm{~nm}$ decreases. This band is characteristic for $\mathrm{Co}(\mathrm{III})$ and the second electron transfer is therefore proposed to occur at the cobalt center. However for conjugate 4, only a one step electron transfer is observed during the first oxidation, and the spectral changes are similar to the initial oxidation step of conjugate $\mathbf{6}$. The results indicate that for conjugate $\mathbf{4}$, the electron transfer occurs at only the porphyrin $\pi$-ring system in the first oxidation while for conjugate $\mathbf{6}$, a two step electron transfer occurs during the first oxidation process, one electron being abstracted from the porphyrin $\pi$-ring system and another from the cobaltabisdicarbollide group.

\section{Supplementary Material}

Refer to Web version on PubMed Central for supplementary material.

\section{Acknowledgments}

This work was partially supported by the National Institutes of Health, grant number CA098902 (MGHV). The support of the Robert A. Welch Foundation (Grants E-680 to KMK) is gratefully acknowledged.

\section{LITERATURE CITED}

(1). Kadish, KM.; Smith, KM.; Guilard, R., editors. The Porphyrin Handbook. Academic Press; Boston: 2000.

(2). McLaughl G. Crystal and molecular structure of a non-metallo, $N$-substituted porphyrin, 21ethoxycarbonylmethyl-2,3,7,8,12,13,17,18-octaethylporphyrin. J. Chem. Soc., Perkin Trans. 1974; 2:136-140.

(3). Lavallee DK, Kopelove AG, Anderson OP. Structures and properties of Nmethyltetraphenylporphyrin complexes. The crystal and molecular structure of chloro-Nmethyl-.alpha.,.beta.,.gamma.,.delta.-tetraphenylporphinatozinc(II) and the chelate effect of zinc(II), cobalt(II), and cadmium(II) N-methylporphyrin complexes. J. Am. Chem. Soc. 1978; 100:3025-3033. 
(4). Lavallee, DK. The Chemistry and Biochemistry of N-Substituted Porphyrins. VCH Publishers; Weinheim: 1987.

(5). Venkateshrao S, Yin J, Jarzecki AA, Schultz PG, Spiro TG. Porphyrin distortion during affinity maturation of a ferrochelatase antibody, monitored by resonance raman spectroscopy. J. Am. Chem. Soc. 2004; 126:16361-16367. [PubMed: 15600337]

(6). Jarzecki AA, Spiro TG. Porphyrin Distortion from Resonance Raman Intensities of Out-of-Plane Modes: Computation and Modeling of N-Methylmesoporphyrin, a Ferrochelatase Transition State Analog. J. Phys. Chem. A. 2005; 109:421-430. [PubMed: 16833362]

(7). Cochran AG, Schultz PG. Antibody-catalyzed porphyrin metallation. Science. 1990; 249:781-783. [PubMed: 2389144]

(8). Dailey, HA. Mechanisms of Metallocenter Assembly. Eichorn, GL.; Marzilli, LG.; Hausinger, RP., editors. VCH; New York: 1996. p. 77-89.

(9). Ito A, Konishi K, Aida T. Free bases of chiral $N$-substituted porphyrins as catalysts for asymmetric reaction. Tetrahedron Lett. 1996; 37:2585-2588.

(10). Konishi K, Yahara K, Toshishige H, Aida T, Inoue S. A novel anion-binding chiral receptor based on a metalloporphyrin with molecular asymmetry. Highly enantioselective recognition of amino acid derivatives. J. Am. Chem. Soc. 1994; 116:1337-1344.

(11). Setsune J-I, Takeda H. Synthesis of N,N'-(trimethylene)-linked porphyrin-cyclen composite. Tetrahedron Lett. 1995; 33:5903-5904.

(12). Lavallee DK, Xu Z, Pina R. Synthesis and properties of new cationic-periphery porphyrins, tetrakis(p-(aminomethyl)phenyl)porphyrin and N-methyltetrakis(p(aminomethyl)phenyl)porphyrin. J. Org. Chem. 1993; 58:6000-6008.

(13). Tsukahara K, Sawai N, Hamada S, Koji K, Onoue Y, Nakazawa T, Nakagaki R, Nozaki K, Ohno T. Photophysical and photochemical properties of viologen-linked $N$-Alkylporphyrin diads and their metal complexes. J. Phys. Chem. B. 1999; 103:2867-2877.

(14). Vicente, MGH. Reactivity and functionalization of b-substituted porphyrins and chlorins. In: Kadish, KM.; Smith, KM.; Guilard, R., editors. The Porphyrin Handbook. Vol. Volume 1: Synthesis and Organic Chemistry. Academic Press; Boston: 2000. p. 149-199.Chapter 42000

(15). Ishimaru Y, Sumida S, Iida T. Regio- and stereoselective reduction of intramolecular $N$-strapped porphyrins to phlorins. Tetrahedron Lett. 2001; 42:419-421.

(16) a). Ruppert R, Jeandon C, Sgambati A, Callot HL. Reduction of $N$-arylporphyrins to $N$ arylphlorins: opposite stereochemical courses as a function of the reducing agent. Chem. Comm. 1999:2123-2124.b) Krattinger B, Callot HJ. Alkylation and reduction of porphyrins and Nsubstituted porphyrins: new routes to chlorins and phlorins. Eur. J. Org. Chem. 1999:18571867.c) Smith KM, Pandey PK, Snow KM. Nickel(II)-promoted rearrangements of some $N$ substituted porphyrins. J. Chem. Soc. Chem. Comm. 1986:1498-1499.

(17). Paolesse R, Nardis S, Stefanelli M, Fronczek FR, Vicente MGH. Hemiporphycene from Expansion of a Corrole Ring. Angew. Chem. Int. Ed. 2005; 44:3047-3050.

(18). Barth RF, Coderre JA, Vicente MGH, Blue TE. Boron neutron capture therapy of cancer: current status and future prospects. Clin. Cancer Res. 2005; 11:3987. [PubMed: 15930333]

(19). Renner MW, Miura M, Easson MW, Vicente MGH. Recent progress in the syntheses and biological evaluation of boronated porphyrins for boron neutron-capture therapy. Curr. Med. Chem. Anti-Cancer Agents. 2006; 6:145-158.

(20). Sivaev IB, Bregadze VI. Chemistry of cobalt bis(discarbollides). A review. Collect. Czech. Chem. Commun. 1999; 64:783-805.

(21) a). Hao E, Vicente MGH. Expeditious synthesis of porphyrin-cobaltacarborane conjugates. Chem. Commun. 2005:1306-1308.b) Hao E, Jensen TJ, Courtney BH, Vicente MGH. Synthesis and cellular studies of porphyrin-cobaltacarborane conjugates. Bioconjugate Chem. 2005; 16:1495-1502.c) Sibrian-Vazquez M, Hao E, Jensen TJ, Vicente MGH. Enhanced cellular uptake with a cobaltacarborane-porphyrin-HIV-1 Tat 48-60 conjugate. Bioconjugate Chem. 2006; 17:928-934.d) Hao E, Sibrian-Vazquez M, Fronczek FR, Garno J, Vicente MGH. Syntheses, Aggregation and Cellular studies of Porphyrin-cobaltacarborane Conjugates. Chem. Eur. J. 2007; 32:9035-9042. 
(22). Lin XQ, Kadish KM. Vacuum-tight thin-layer spectroelectrochemical cell with a doublet platinum gauze working electrode. Anal. Chem. 1985; 57:1498-1501. [PubMed: 4037326]

(23). Luguya R, Jaquinod L, Fronczek FR, Vicente MGH, Smith KM. Synthesis and reactions of meso-(p-nitrophenyl)porphyrins. Tetrahedron. 2004; 60:2757-2763.

(24). Otwinowski, Z.; Minor, W. Processing of X-ray diffraction data collected in oscillation mode. In: Carter, CW., Jr; Sweet, RM., editors. Methods in Enzymology. Vol. Volume 276:

Macromolecular Crystallography, Part A. Academic Press; New York: 1997. p. 307-326.

(25). Sheldrick, GM. SHELXL97. University of Göttingen; Germany: 1997.

(26). Plešek J, Heřmánek S, Franken A, Cisarova I, Nachtigal C. Dimethyl Sulfate Induced Nucleophilic Substitution of the [Bis(1,2-dicarbollido)-3-cobalt(1-)]ate Ion. Syntheses, Properties and Structures of Its 8,8'- $\mu$-Sulfato, 8-Phenyl and 8-Dioxane Derivatives. Collect. Czech. Chem. Commun. 1997; 62:47-56.

(27). Teixidor F, Pedrajas J, Rojo I, Vinas C, Kivekas R, Sillanpaa R, Sivaev I, Bregadze V, Sjoberg S. Chameleonic Capacity of [3,3'-Co(1,2- $\left.\left.\mathrm{C}_{2} \mathrm{~B}_{9} \mathrm{H}_{11}\right)_{2}\right]$ in Coordination. Generation of the Highly Uncommon S(thioether)-Na Bond. Organometallics. 2003; 22:3414-3423.

(28). Plešek J, Heřmánek S, Baše K, Todd L, Wright WF. Zwitterionic compounds of the 8,8'-R-3commo-3-cobaltabis(1,2-dicarba-closo-dodecaborane(11)). Collect. Czech. Chem. Commun. 1976; 41:3509-3515.

(29). Šubrtová V, Petřiček V, Linek A, Jecny J. The crystal and molecular structure of 8,8'$\mathrm{OCH}_{3}\left(\mathrm{~B}_{9} \mathrm{C}_{2} \mathrm{H} 10\right)_{2} \mathrm{Co} . \mathrm{Z}$. Kristallogr. 1976; 144:139-141.

(30). Abeysekera AM, Grigg R, Trocha-Grimshaw J, Henrick K. N-methylation of etioporphyrin I and octaalkyl-5-azaporphyrins: $\mathrm{x}$-ray structure of trans- $\mathrm{N}_{\mathrm{a}}, \mathrm{N}_{\mathrm{b}}$-dimethyletioporphyrin I triiodide. Tetrahedron. 1980; 36:1857-1868.

(31). McLaughl G. Crystal and molecular structure of a non-metallo, $N$-substituted porphyrin, 21ethoxycarbonylmethyl-2,3,7,8,12,13,17,18-octaethylporphyrin. J. Chem. Soc., Perkin Trans. 1974; 2:136-139.

(32). Lavallee DK, Anderson OP. Crystal and molecular structure of a free-base N-Methylporphyrin: N-Methyl-5,10,15,20-tetrakis(p-bromophenyl)porphyrin. J. Am. Chem. Soc. 1982; 104:47074708.

(33). McLaughlin GM. Crystal and molecular structure of 1,3,6,8-tetra-azatricyclo[4.4.1.1 $\left.{ }^{3,8}\right]$ dodecane, the 2:1 condensation product of formaldehyde and 1,2-diaminoethane, and the conformation of this system. J. Chem. Soc. Perkin Trans. 1974; 2:136-140.

(34). Al-Hazimi HMG, Jackson AH, Johnson AW, Winter M. N-methylated tetraphenylporphins. J. Chem. Soc. Perkin I. 1977:98-103.

(35). Senge MO, Kalisch WW, Runge S. N-Methyl derivatives of highly substituted porphyrins - the combined influence of both core and peripheral substitution on the porphyrin conformation. Liebigs Ann. Recueil. 1997:1345-1352.

(36). Stolzenberg AM, Simerly SW, Steffey BD, Haymond GS. The synthesis, properties, and reactivities of free-base and $\mathrm{Zn}(\mathrm{II})-\mathrm{N}$-Methyl hydroporphyrin compounds. The unexpected selectivity of the direct methylation of free-base hydroporphyrin compounds. J. Am. Chem. Soc. 1997; 119:11843-11854.

(37) a). Broadhurst ML, Grigg R, Shelton G. $N$ - Alkylation of porphins and related macrocycles. J. Chem. Soc. Chem. Comm. 1970:231-233.b) Grigg R, Shelton G, Sweeney A, Johnson AW. Nmethylation and electrophilic substitution reactions of octa-alkyl-porphins, octaethylchlorin, and metalloporphins. J. Chem. Soc. Perkin I. 1972:1789-1799.

(38). Rudakov DA, Shirokii VL, Knizhnikov VA, Bazhanov AV, Vecher EI, Maier NA, Potkin VI, Ryabtsev AN, Petrovskii PV, Sivaev IB, Bregadze VI, Eremenko IL. Electrochemical synthesis of halogen derivatives of bis(1,2-dicarbollyl)cobalt(III). Russ. Chem. Bull. 2004; 53:2554-2557.

(39). Kadish, KM.; Caemelbecke, EV.; Royal, G. Electrochemistry of metalloporphyrins in nonaqueous media. In: Kadish, KM.; Smith, KM.; Guilard, R., editors. The Porphyrin Handbook. Vol. Volume 8: Electron Transfer. Academic Press; Boston: 1999. p. 1-97.Chapter 55

(40). Kadish, KM.; Royal, G.; Caemelbecke, EV.; Gueletti, L. Metalloporphyrins in Nonaqueous Media: Database of Redox Potentials. In: Kadish, KM.; Smith, KM.; Guilard, R., editors. The 
Porphyrin Handbook. Vol. Volume 9: Database of Redox Potentials and Binding Constants. Academic Press; Boston: 1999. p. 90-117.Chapter 59

(41). Kadish, KM. The electrochemistry of metalloporphyrins in nonaqueous media. In: Lippard, SJ., editor. Progress in Inorg. Chem. Vol. Volume: 34. John Wiley; New York: 1986. p. 435-605.

(42). Malinski T, Chang D, Bottomley LA, Kadish KM. Substituent effects on the redox reactions of para-substituted tetraphenylporphyrin complexes of ruthenium(II). Inorg. Chem. 1982; 21:42484253.

(43). Bettelheim A, White BA, Raybuck SA, Murray RW. Electrochemical polymerization of amino-, pyrrole-, and hydroxy-substituted tetraphenylporphyrins. Inorg. Chem. 1987; 26:1009-1017.

(44). Guilard R, Barbe JM, Fahim M. Synthesis of carbenoid-bonded binuclear porphyrins which contain a single hydrophobic chain. Spectroscopic and electrochemical characterization of (P)SnFe(CO)4. New J. Chem. 1992; 16:815-820. 


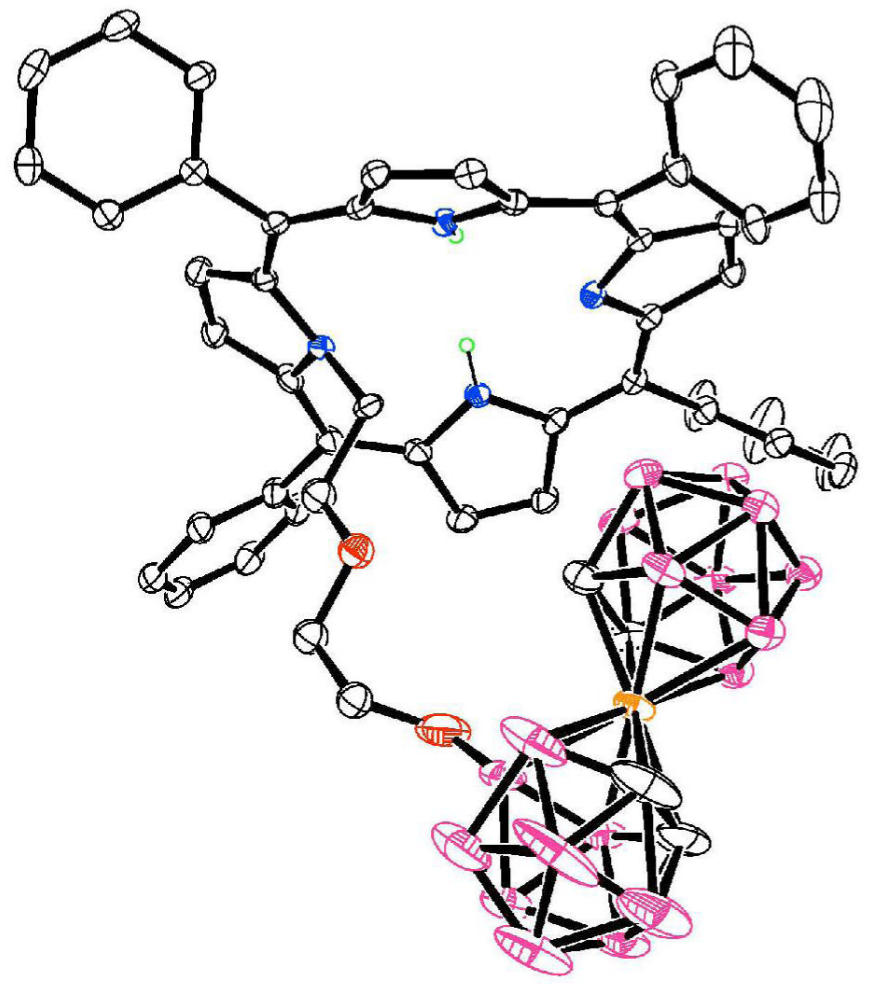

Figure 1.

Molecular structure of N-cobaltacarborane porphyrin 3. The pyridine and water molecules are not shown for clarity. 


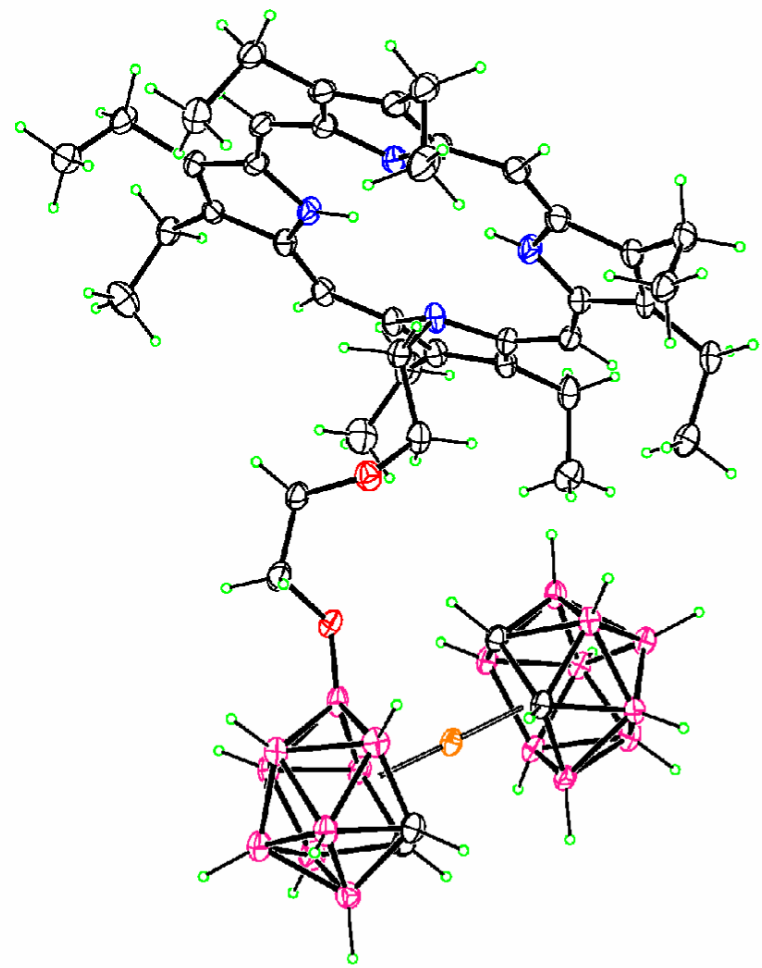

Figure 2.

Molecular structure of N-cobaltacarborane porphyrin 4. 

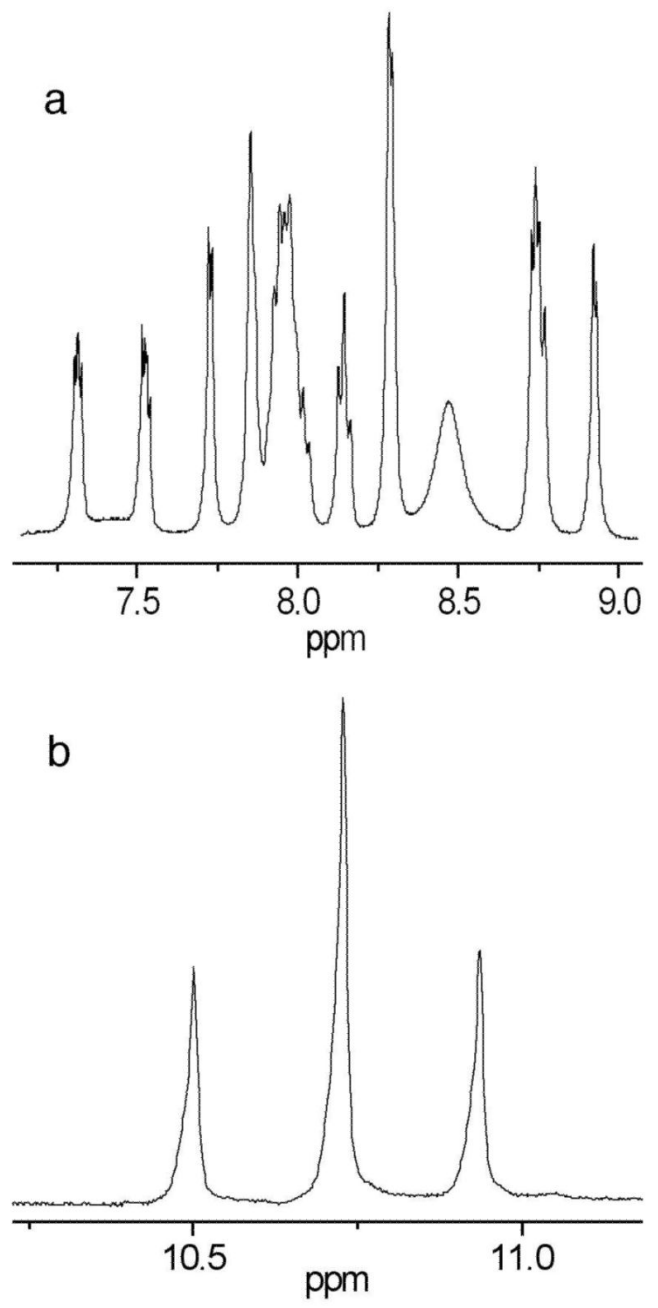

Figure 3.

${ }^{1} \mathrm{H}-\mathrm{NMR}$ (aromatic region only) in acetone-d ${ }^{6}$ of a) porphyrin 5 and b) porphyrin 6. 


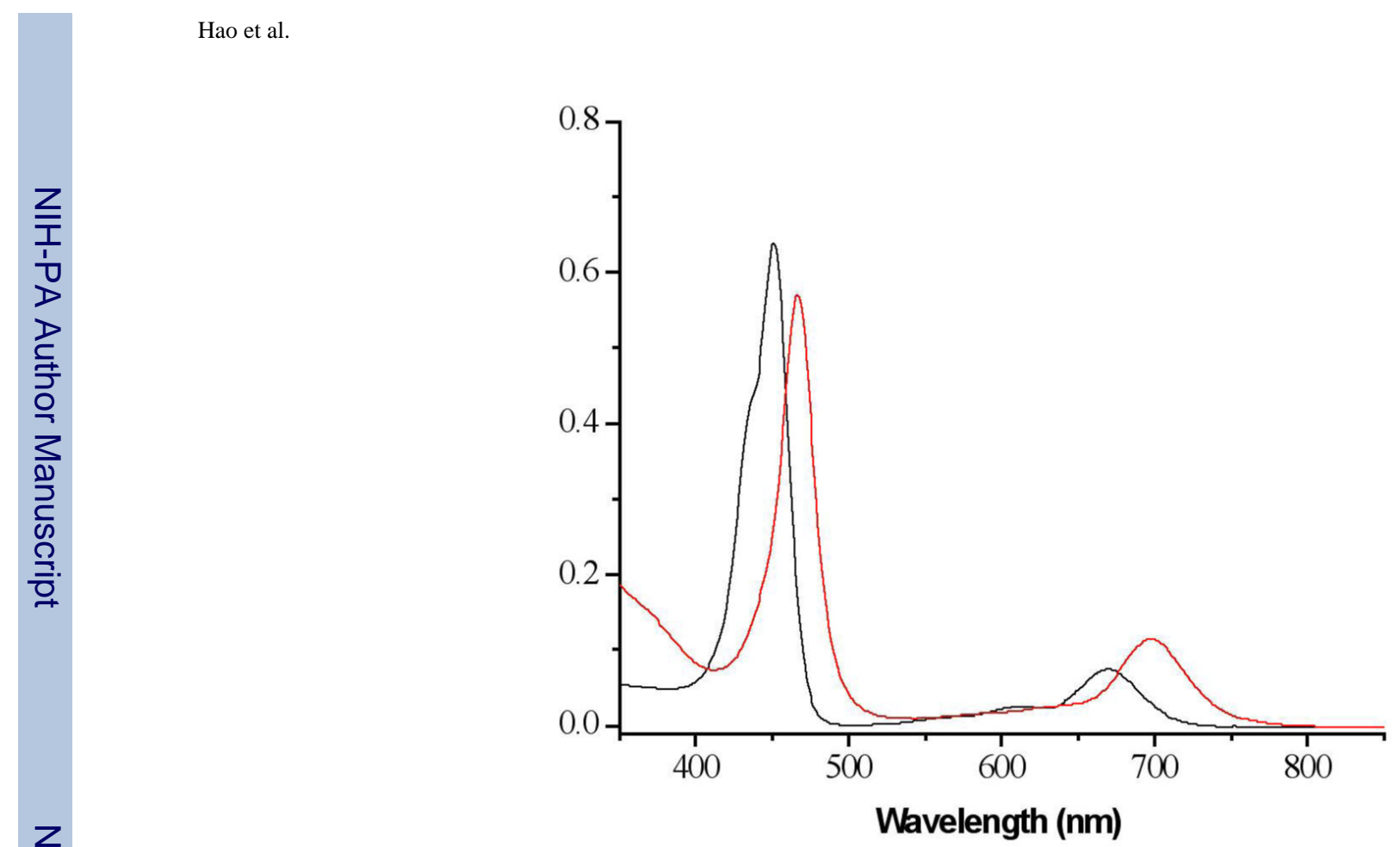

Figure 4.

UV-visible spectra of porphyrins 3 (black) and $\mathbf{5}$ (red) in acetone at $2 \times 10^{-6} \mathrm{M}$. 


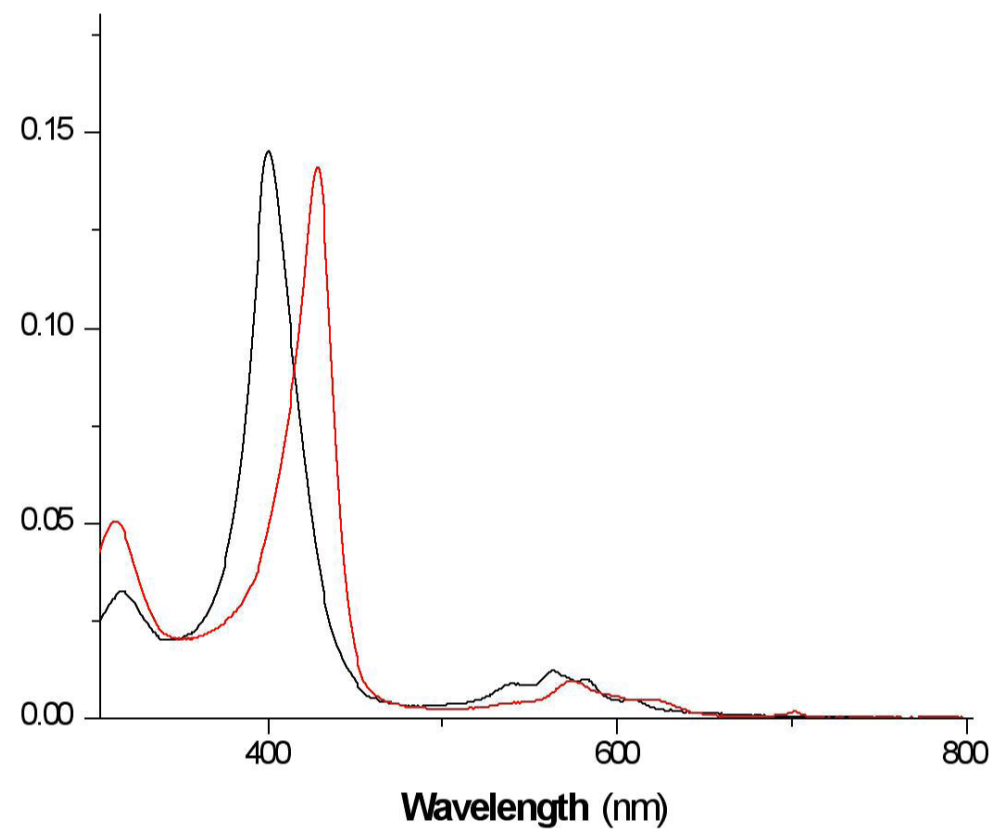

Figure 5.

$\mathrm{UV}$-visible spectra of porphyrins 4 (black) and 6 (red) in acetone at $1 \times 10^{-6} \mathrm{M}$. 


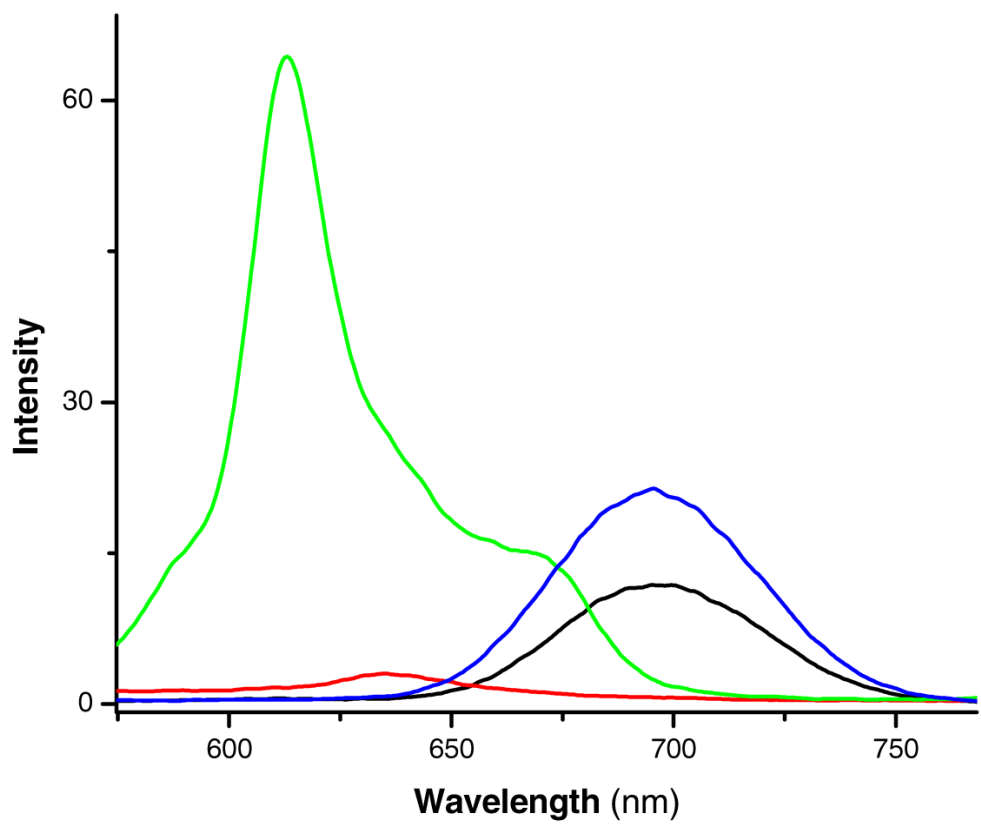

Figure 6.

Fluorescence spectra of porphyrins 3 (blue), 5 (black), 4 (green) and $\mathbf{6}$ (red) in acetone at $1 \times$ $10^{-6} \mathrm{M}$ 


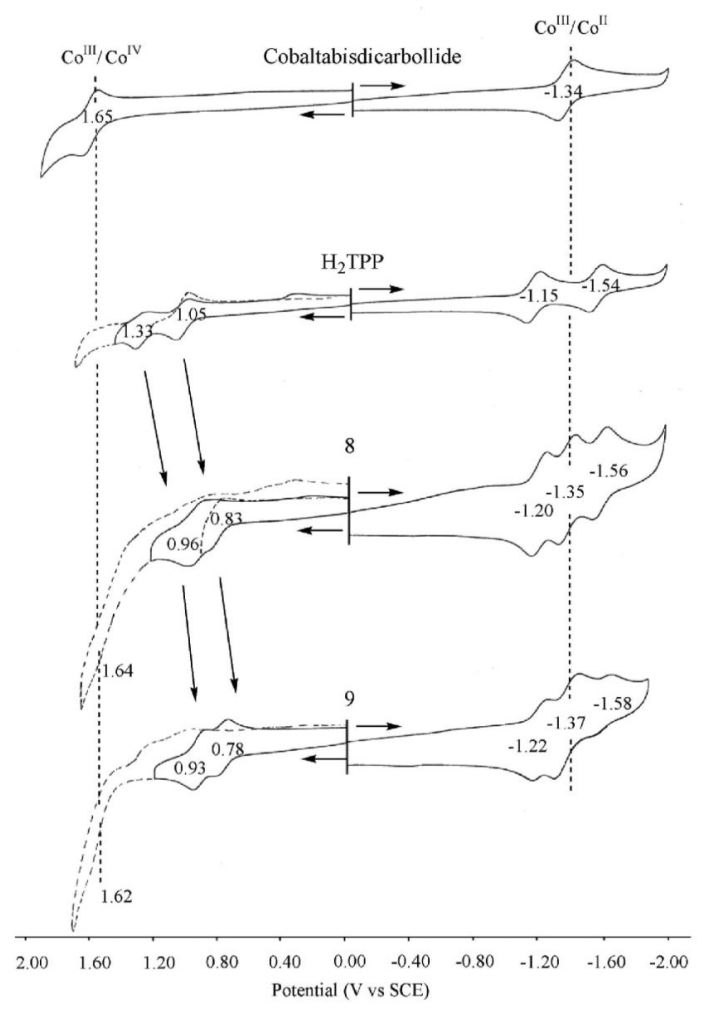

Figure 7.

Cyclic voltammograms of cabaltabisdicarbollide, $\mathrm{H}_{2}$ TPP and meso-substituted conjugates 8 and 9 in PhCN containing 0.1 M TBAP. 

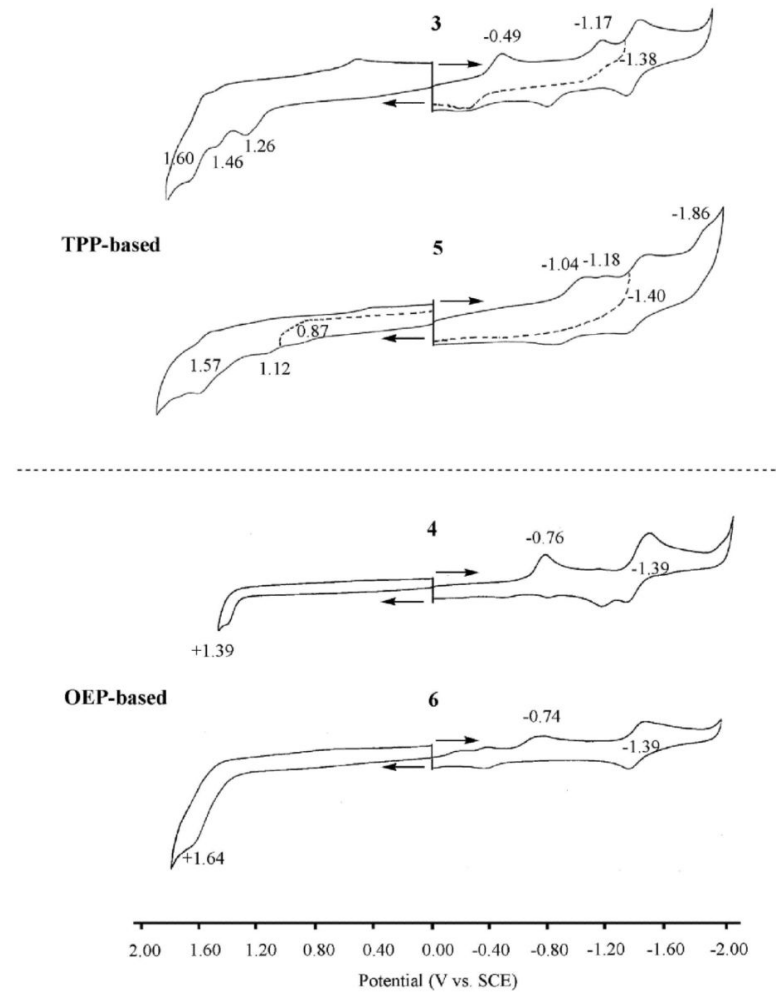

Figure 8.

Cyclic voltammograms of $N$-substituted conjugates 3-6 in PhCN containing 0.1 M TBAP. 

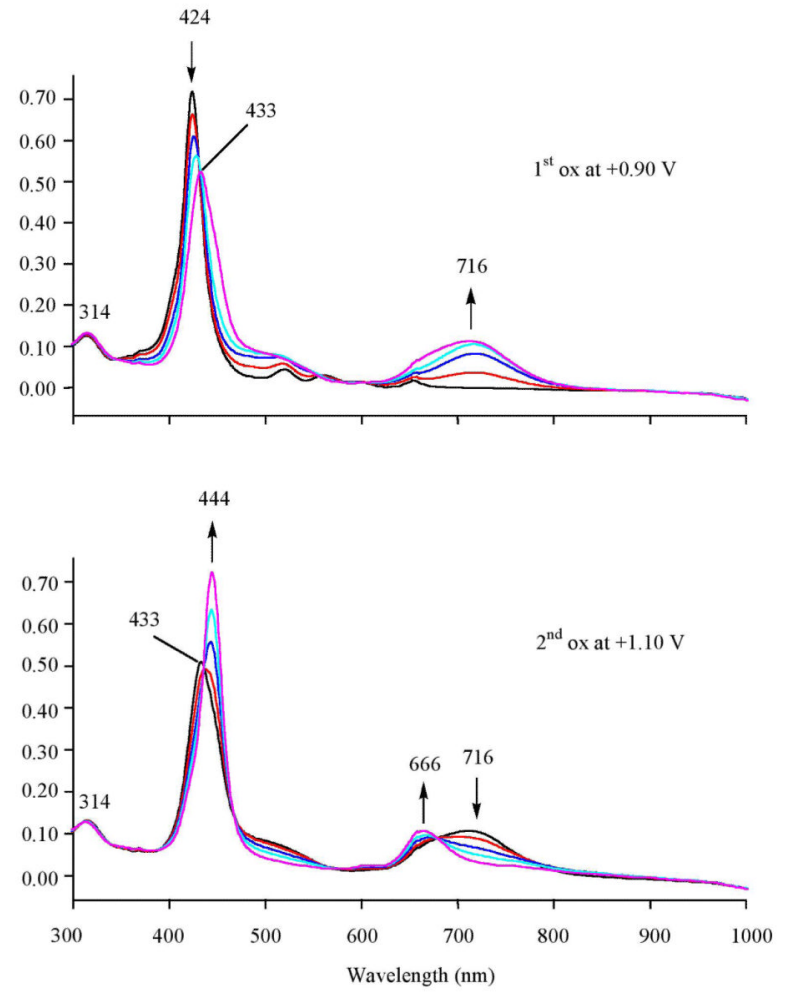

Figure 9.

Thin-layer UV-visible spectral changes upon the (a) first and (b) second oxidations of porphyrin conjugate 8 in PhCN containing 0.1 M TBAP. 


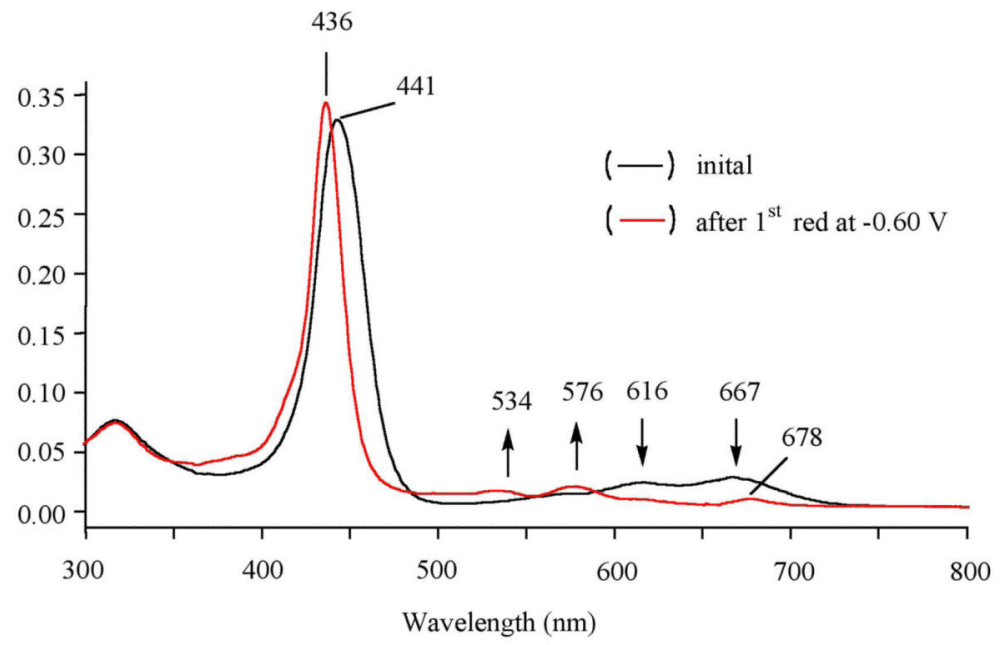

Figure 10.

Thin-layer UV-visible spectral changes before (black line) and after (red line) the first reduction of porphyrin conjugate 3 in PhCN, 0.1 M TBAP. 


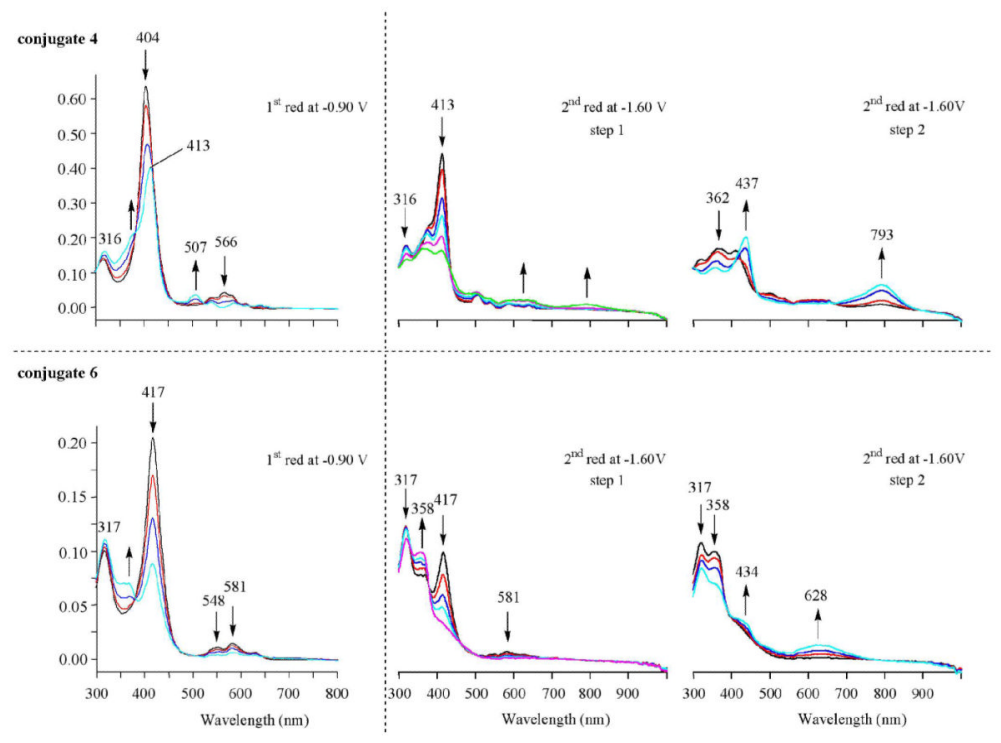

Figure 11.

Spectral changes of the $\mathrm{H}_{2} \mathrm{OEP}$ based $N$-substituted conjugates 4 (top) and $\mathbf{6}$ (bottom) during reduction processes in $\mathrm{PhCN}$ containing 0.1 M TBAP. 


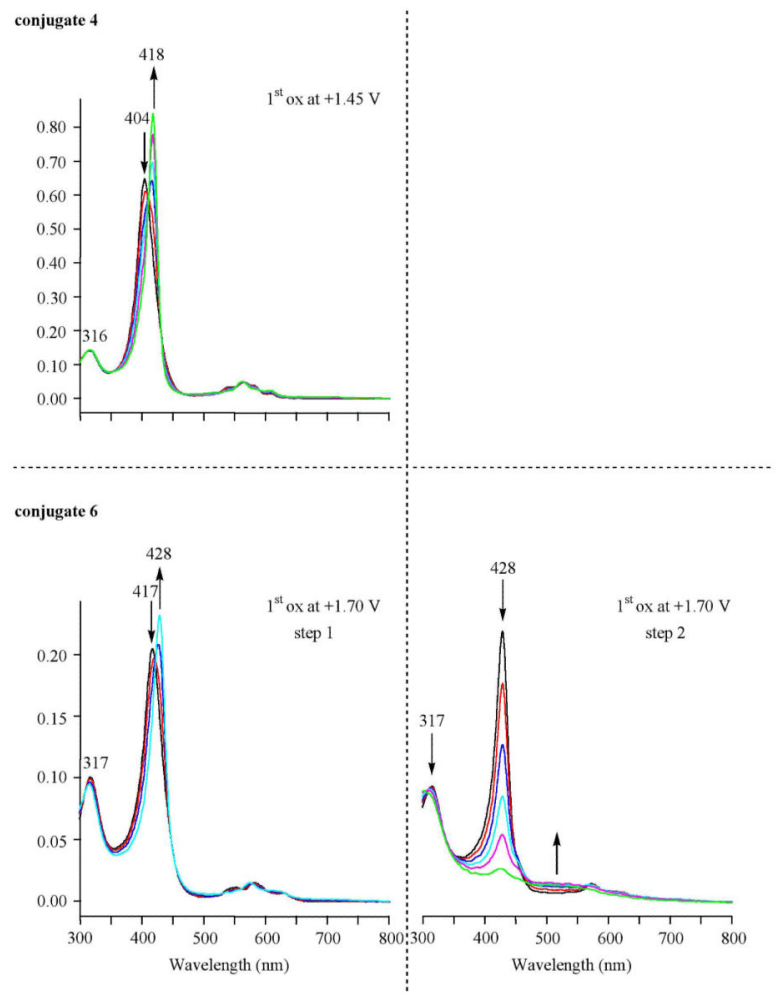

Figure 12.

Spectral evolutions of the $\mathrm{H}_{2} \mathrm{OEP}$ based $N$-substituted conjugates 4 (top) and 6 (bottom) during oxidation processes in PhCN containing 0.1 M TBAP. 


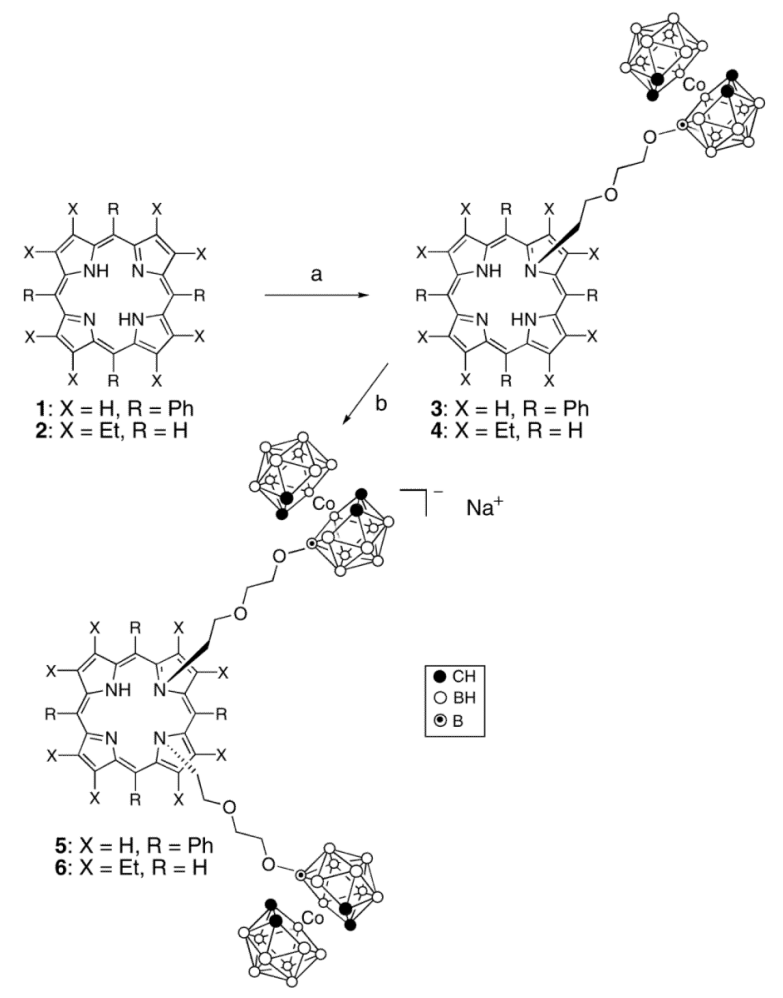

Scheme 1a.

${ }^{a}$ Conditions: (a) [3,3'- $\left.\mathrm{Co}\left(8-\mathrm{C}_{4} \mathrm{H}_{8} \mathrm{O}_{2}-1,2-\mathrm{C}_{2} \mathrm{~B}_{9} \mathrm{H}_{10}\right)\left(1^{\prime}, 2^{\prime}-\mathrm{C}_{2} \mathrm{~B}_{9} \mathrm{H}_{11}\right)\right]$, ODCB, $140{ }^{\circ} \mathrm{C}, 2 \mathrm{~h}$ (81-89\%); (b) [3,3'-Co(8- $\left.\left.\mathrm{C}_{4} \mathrm{H}_{8} \mathrm{O}_{2}-1,2-\mathrm{C}_{2} \mathrm{~B}_{9} \mathrm{H}_{10}\right)\left(1^{\prime}, 2^{\prime}-\mathrm{C}_{2} \mathrm{~B}_{9} \mathrm{H}_{11}\right)\right], \mathrm{NaHCO}_{3}, \mathrm{ODCB} 140{ }^{\circ} \mathrm{C}$, $2 \mathrm{~h}(73-83 \%)$. 


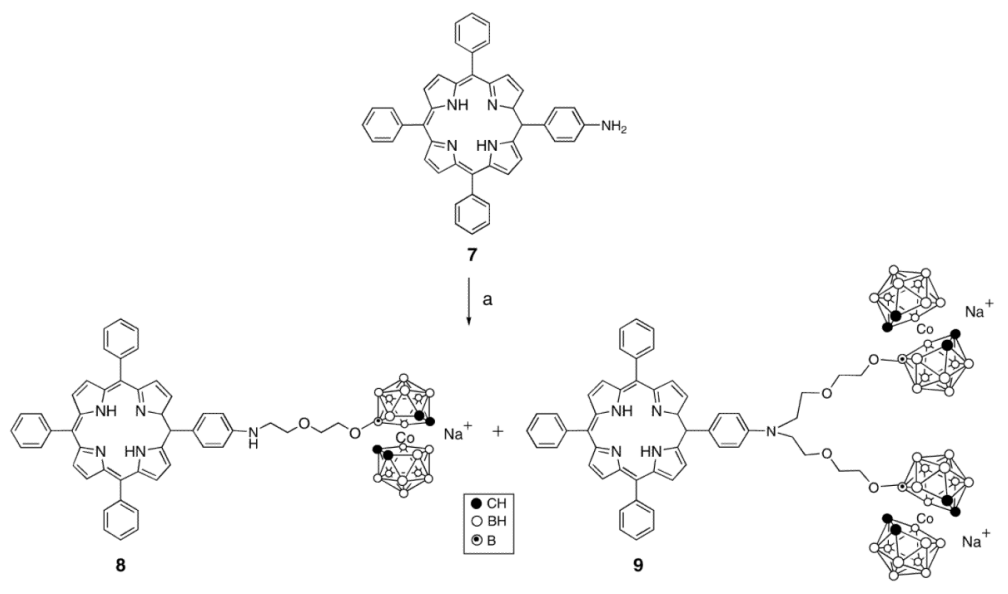

Scheme 2a.

${ }^{a}$ Conditions: (a) [3, 3'- $\left.\mathrm{Co}\left(8-\mathrm{C}_{4} \mathrm{H}_{8} \mathrm{O}_{2}-1,2-\mathrm{C}_{2} \mathrm{~B}_{9} \mathrm{H}_{10}\right)\left(1^{\prime}, 2^{\prime}-\mathrm{C}_{2} \mathrm{~B}_{9} \mathrm{H}_{11}\right)\right], \mathrm{CHCl}_{3} / \mathrm{CH}_{3} \mathrm{CN} 1: 1$, reflux ( $46 \%$ of $\mathbf{8}$ and $26 \%$ of $\mathbf{9})$. 
Reduction

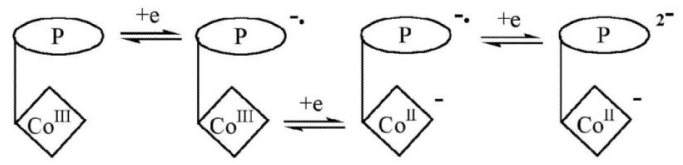

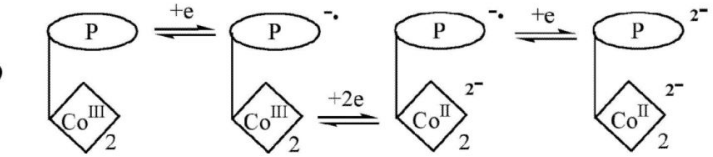

Oxidation

8

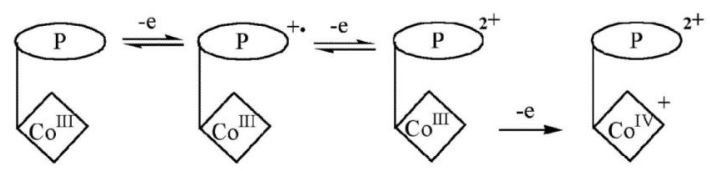

9

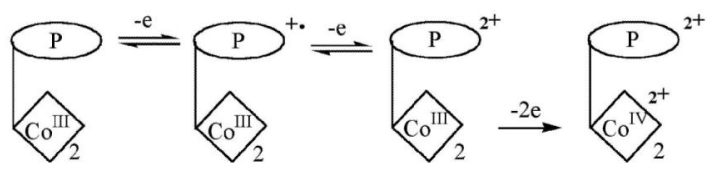

Scheme 3a.

${ }^{a}$ Site of electron transfer at the porphyrin or cabaltabisdicarbollide part of conjugates $\mathbf{8}$ and 9. 


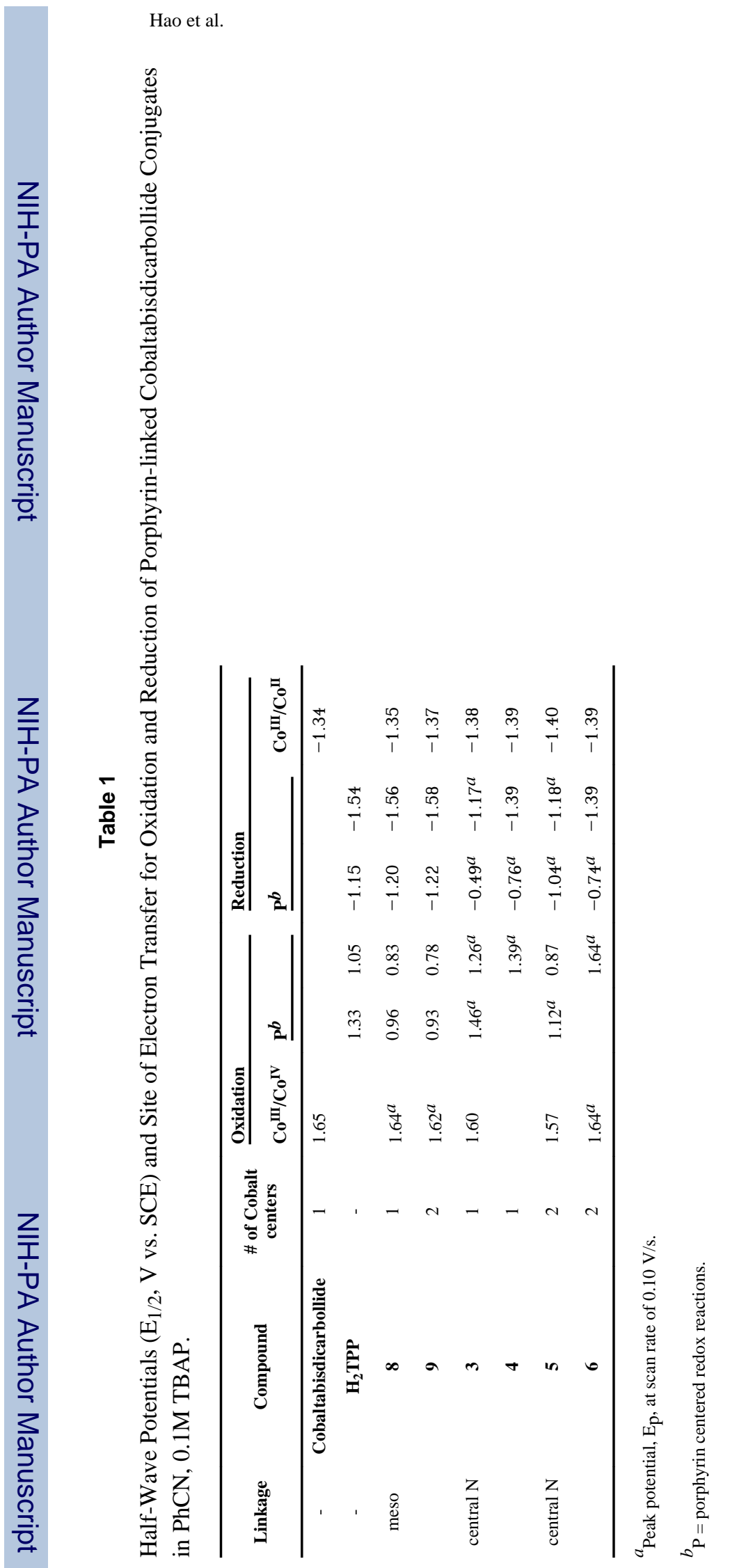

Bioconjug Chem. Author manuscript; available in PMC 2011 August 29. 


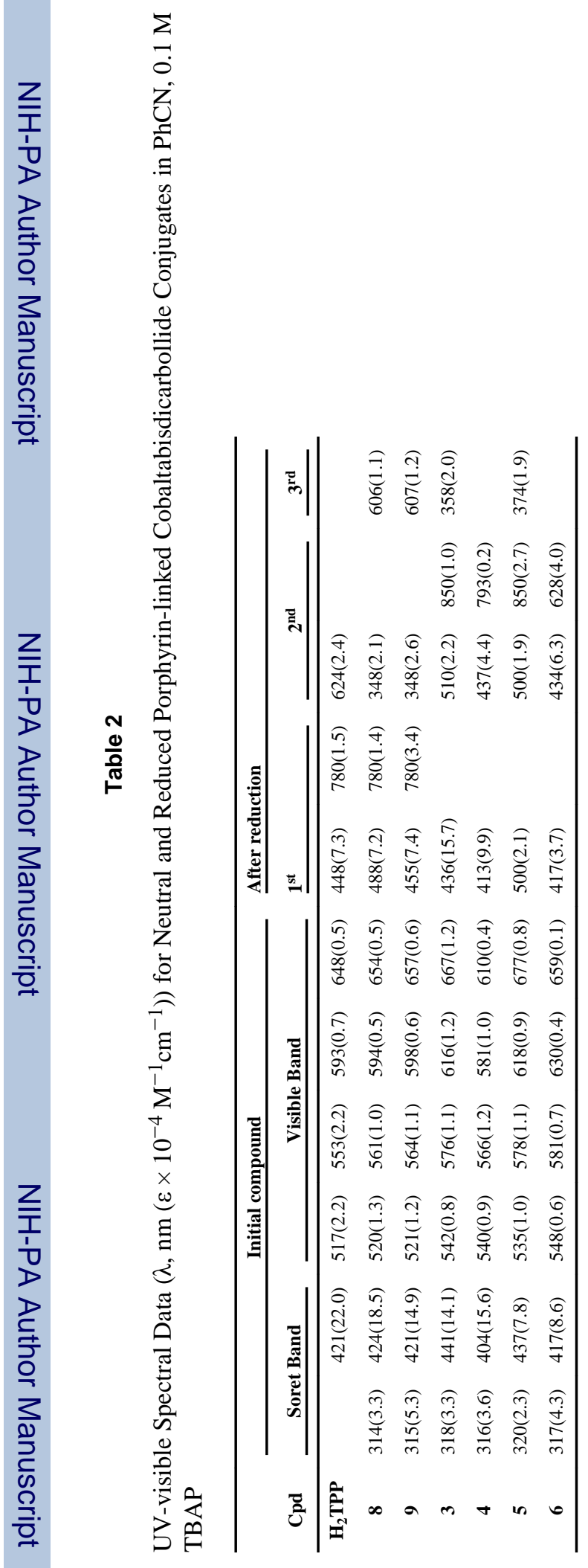

